\title{
Restoration ecology of coastal lagoons: new methods for the prediction of ecological trajectories and economic valuation
}

\author{
De Wit Rutger ${ }^{1,{ }^{*}}$, Rey-Valette Helene ${ }^{2}$, Balavoine Juliette ${ }^{1,3}$, Ouisse Vincent ${ }^{4}$, Lifran Robert ${ }^{2}$ \\ ${ }^{1}$ Centre for Marine Biodiversity; Exploitation and Conservation (MARBEC), IRD, Ifremer, Université de \\ Montpellier; Montpellier France \\ 2 UMR LAMETA; INRA, Université de Montpellier; Montpellier France \\ ${ }^{3}$ Plan Bleu pour la Méditerranée; PAM/PNUE Regional Activity Centre; Valbonne France \\ ${ }^{4}$ Centre for Marine Biodiversity; Exploitation and Conservation (MARBEC), IRD, Ifremer, Université de \\ Montpellier; Sète France \\ * Corresponding author : Rutger De Wit, email address : rutger.de-wit@umontpellier.fr
}

\begin{abstract}
:
Conservation of the seven lagoons of the Palavas complex (southern France) has been severely impaired by nutrient over-enrichment during at least four decades. The effluents of the Montpellier wastewater treatment plant (WWTP) represented the main nutrient input. To improve the water quality of these lagoons, this WWTP was renovated and upgraded and, since the end of 2005, its effluents have been discharged $11 \mathrm{~km}$ offshore into the Mediterranean (total investment $€ 150 \mathrm{M}$ ).
\end{abstract}

Possibilities of ecosystem restoration as part of a conservation programme were explored by a focus group of experts. Their tasks were: (i) to evaluate the impact of the reduction of the nutrient input; (ii) if necessary, to design additional measures for an active restoration programme; and (iii) to predict ecosystem trajectories for the different cases. Extension of Magnoliophyta meadows can be taken as a proxy for ecosystem restoration as they favour the increase of several fish (seahorse) and bird (ducks, swans, herons) species, albeit they represent a trade-off for greater flamingos. Additional measures for active ecosystem restoration were only recommended for the most impaired lagoon Méjean, while the least impaired lagoon Ingril is already on a trajectory of spontaneous recovery.

A multiple contingent valuation considering four different management options for the Méjean lagoon was used in a pilot study based on face-to-face interviews with 159 respondents. Three levels of ecosystem restoration were expressed in terms of recovery of Magnoliophyta meadows, including their impact on emblematic fish and avifauna. These were combined with different options for access (status quo, increasing access, increasing access with measures to reduce disturbance). The results show a willingness of local populations to pay per year about $€ 25$ for the highest level of ecological restoration, while they were only willing to allocate about $€ 5$ for additional footpaths and hides.

Keywords: coastal lagoon, seagrass meadow, marine and brackish Magnoliophyta, phytoplankton, ecosystem services, willingness to pay (WTP), ecosystem trajectory' nutrient enrichment, oligotrophication, sediment $\mathrm{N}$ and $\mathrm{P}$ contents, Water Framework Directive 


\section{INTRODUCTION}

Coastal lagoons occupy about $13 \%$ of the world's coastlines (Barnes, 1980) and about $5.5 \%$ of the European coast (Razinkovas et al., 2008), where they are particularly abundant around the Mediterranean Sea and the South-eastern Baltic coasts. Their surroundings represent attractive sites for human development and lagoons are exploited for different uses including fisheries, aquaculture, recreation and tourism (Anthony et al., 2009, Kuhfuss et al., 2010). Water quality and biodiversity in coastal lagoons are particularly vulnerable towards high nutrient and contaminant loadings from their watersheds and, in general, coastal lagoons suffer from increasing demographic and economic developments in the coastal zone. Hence, despite the fact that conservation measures including designations as natural parks, regional nature reserves, "Natura 2000" and "Ramsar" sites have been applied to many coastal lagoon sites in Europe, many of these ecosystems have been degraded by anthropogenic pressures, among which eutrophication has been particularly important (Zaldivar et al., 2008).

In coastal lagoons the impact of eutrophication on ecosystem structure and functioning is characterized by regime shifts that are well documented in the scientific literature (Nixon 1995, Valiela et al., 1997; Schramm, 1999; De Wit et al., 2001; Orfanidis et al., 2003; Viaroli et al., 2008). The different stages are described briefly. Oligotrophy in coastal lagoons, which typically represents the pristine situation for many of them, is characterized by low water column turbidity due to low phytoplankton densities. In the South of France it has been shown that phytoplankton growth in oligotrophic lagoons is limited by phosphorus supply (Souchu et al., 2010). The low water turbidity favours a submerged aquatic vegetation (SAV) of Magnoliophyta, comprising seagrasses in polyhaline and mixoeuhaline lagoons, while freshwater and brackish species may occur in oligohaline and mesohaline lagoons. At a low level of nutrient loading the Magnoliophyta grow vigorously. However, as loading increases, a first intermediate stage is characterized by heavy growth of epiphytes on the leaves and stems of the Magnoliophyta, which may induce a shading stress for the latter. As nutrient loading further increases, the system may flip over into another state dominated either by opportunistic macroalgae or by a dense phytoplankton bloom. Macroalgal-dominated systems are susceptible to develop dystrophic crises during summer with water column hypoxia following a sudden crash of the algal blooms (Valiela et al., 1997; De Wit et al., 2001; Viaroli et al., 2008). Extremely high loading often results in primary producer communities dominated by phytoplankton species, i.e. often picoeukaryotes in hypertrophic Mediterranean lagoons (Bec et al., 2011) and filamentous cyanobacteria in oligohaline systems (Pilkaitytė and Razinkovas, 2006; Chomérat et al., 2007). Insufficient light availability close to the bottom is a major key factor explaining the absence of SAV in coastal systems, illustrated by the fact that the depth limit for the establishment of SAV decreases with increasing eutrophication (Duarte, 1991).

The general aim of improving the water quality and ecological conditions in surface waters as requested in the European Union by the Water Framework Directive (Council of the European Communities, 2000) thus clearly converges with the objective of the conservation of valuable aquatic ecosystems such as coastal lagoons. Before 2000, interventions to reduce the stress caused by eutrophication in Mediterranean coastal lagoons have included: i) macroalgal harvesting (Guyoneaud et al., 1998; Lenzi et al, 2003), 
and ii) measures for improving water exchange with the adjacent sea. Nowadays, it is considered that the reduction of nutrient loading to coastal lagoons is of primary importance to combat eutrophication and prevent dystrophic crises in coastal lagoons. Therefore, a lot of efforts have been spent in upgrading sewage collection systems and wastewater treatment plants (WWTP) and in some cases the output of the WWTP bypasses the lagoon and is discharged into the open sea as is the case for the Bassin d'Arcachon (De Wit et al., 2005) and for the Mediterranean lagoons of the Palavasian complex close to Montpellier (see detail below).

Ecological restoration is the process of assisting the recovery of an ecosystem that has been degraded, damaged, or destroyed (Society for Ecological Restoration International Science \& Policy Working Group, 2004). Hence, human intervention focused on reducing the pressures on ecosystems with the aim of recovering the earlier existing ecosystem structure and functioning is clearly part of ecological restoration. It remains, however, an open question whether the suppression of the main pressure, i.e. nutrient overenrichment, is sufficient for a return to historical ecosystem conditions. Borja et al. (2010) review marine and coastal systems where a reduction of the main pressure was realized and evaluates if, and how quickly, the ecosystem returns to its state prior to its degradation. Ecosystem trajectories for return may show hysteresis with respect to their degradation, particularly when regime shifts are based on existence of multiple stable states. It has also been questioned whether marine and coastal ecosystems can return per se to their pristine conditions (Elliot et al., 2007; Duarte et al., 2009). In the context of this paper, passive restoration is defined as the suppression of the external pressure that caused the degradation without taking additional measures. It assumes that after the pressure relieve, a trajectory to recovery of good ecological conditions is based on spontaneous natural processes. For comparison, active restoration implies that the suppression of the causative pressure is accompanied by additional management measures based on direct interventions. Attempts at restoring seagrass meadows in coastal lagoons based on actively planting or seeding is a clear example of such an intervention. A specific theme section of the journal Marine Ecology Progress Series has been devoted to large-scale operations for seagrass recovery in the coastal lagoons of Maryland and Delaware (Orth et al., 2012) and a first pilot experiment has been performed in the south of France (Hebert et al., 2012). While, reducing the external pressures on water bodies clearly is the objective of a general water policy (Council of the European Communities, 2000), the additional measures applied locally in the lagoons should typically be included in the local Master Plans for the conservation and management of lagoons.

The concept of ecosystem services, which has been defined as the benefits that people obtain from ecosystems (Millennium Ecosystem Assessment, 2005), appears appropriate for evaluating how society may benefit from ecosystem conservation and restoration measures. To our knowledge there are very few studies where ecosystem services have been considered for coastal lagoons as an entity. A major database that is now available from case studies on values of ecosystem services of different biomes (De Groot et al., 2012) does not include lagoons as a specific entry, and only one of the cited studies concerns coastal lagoons (Nunes et al., 2004). Similarly, the review of Barbier et al. (2011) about the value of ecosystem services in the coastal zone does not deal with lagoons specifically. In the study by De Groot et al. (2012), some habitats that are typical for coastal lagoons, like seagrass meadows and intertidal flats have been confounded within the biomes 
of coastal systems and coastal wetllands, respectively. Regionally, in South France, an inventory of the ecosystem services of coastal lagoons in the Languedoc-Roussillon region has been compiled using a slight modification of the typology used by the Millennium Ecosystem Assessment (2005), which has served for creating a typology of human uses of lagoons (Kuhfuss et al., 2010). Ecosystem services and human capital has also been a key concept for studying the possibilities of ecosystem restoration of the Etang de Berre lagoon close to Marseille, which has been degraded due to excessive input of fresh water from an electric powerplant (Aronson et al. 2012).

In this paper it is not the aim to determine the total economic value of the ecosystem services (De Groot et al., 2012), which is very demanding and controversial (Norgaard, 2010). In contrast, it was our main interest to assess the marginal economic value, i.e. the value that could be gained by ecological restoration and thus represents the difference between the total economic values of the ecosystem services after and before ecological restoration, respectively. Therefore, different options for the restoration of coastal lagoons have been considered as part of a more comprehensive conservation strategy. Using valuation methods for ecosystem services, the marginal value has been related to the costs of the restoration of ecosystems and been assessed using so-called 'Cost based Methods' (De Groot et al., 2012). These take into account the total amount spent for a realized restoration project, or consider a realistic budget for a planned restoration. Another approach, known as contingent valuation, is to submit a single scenario for a future restoration project, without a clearly established budget, to the general public and ask them their willingness to pay for this project (e.g., Ahtiainen et al., 2013). However, a single scenario is often not satisfactory, as stakeholders often want to consider different alternatives. Hence, participation of stakeholders and general public during the planning phase of a restoration project is obviously most important for its success. Thus, different planning and management options can be developed and proposed to the general public. Ideally, the costs associated with different options have been clearly identified before proposing them to the public. If that is the case, a choice experiment can be used (Westerberg et al., 2010, Jaeck and Lifran, 2013). Unfortunately, so far, it has not been possible to calculate the budgets related to the different restoration options because the data on restoration costs are scarce and highly variable. Namely, each restoration involves specific investments. Therefore, it was decided to prepare four different scenarios for ecosystem restoration and management and each of these four scenarios has been used simultaneously for contingent valuation, referred by us as a multiple contingent valuation (MCV).

This study focused on the coastal lagoons on the Palavasian complex, close to Montpellier. The seven coastal lagoons of this complex have suffered from different degrees of eutrophication, particularly between 1960 and 2005, when the population densities of the Montpellier agglomeration increased by $260 \%$. The nutrient-rich effluents from the WWTP of this urban agglomeration used to be discharged into Lez River, which communicates with the lagoons. In 2005, the WWTP was renovated and upgraded and a 20-km blast pipe was built to implement an offshore outfall system located on the seabed $11 \mathrm{~km}$ from the coast. The total costs of this operation were $€ 150$ million and it resulted in a reduction of $83 \%$ of $N$ and $70 \%$ of $P$ inputs into the lagoon (Meinesz et al., 2013). 
In this study natural sciences and socio-economic research were integrated to develop a novel approach. Therefore, a focus group of experts was formed that concentrated their analyses on two selected lagoons. Based on the knowledge synthesized and recommendations for active restoration scenarios by the focus group a socio-economic questionnaire was designed and used for a multiple contingent valuation (MCV). The objective of this study was to test this new methodology. Hence, it was aimed to synthesize the currently available scientific information in order to predict ecosystem trajectories resulting from nutrient reduction alone (i.e., passive restoration) and how these could be influenced by additional measures (active restoration). The second aim was to analyse the perception of the local populations of ecological restoration of the coastal lagoons and to study their willingness to pay for it.

\section{STUDY AREA}

The lagoons of the Palavasian lagoon complex occur along the SW-NE oriented Mediterranean coastline to the south of the city of Montpellier and are located between 3.76 and $3.96{ }^{\circ} \mathrm{E}$ and between 43.43 and $43.57{ }^{\circ} \mathrm{N}$ (decimal degrees, IGN maps Geoportail http://www.geoportail.gouv.fr). The complex consists of seven lagoons, from west to east, respectively Etang d'Ingril, Etang de Vic, Etang de Pierre Blanche, Etang d'Arnel, Etang du Prévost, Etang du Méjean and Etang du Grec (Figure 1). The word "Etang" is used instead of "lagune" both in the vernacular language and in the official geographic denomination, despite the fact that it formally translates into English as "lake" or "pond". Hereafter, we will replace the word "Etang" by the English word "lagoon"; hence, e.g., Etang d'Ingril will be referred to as Ingril lagoon. These different lagoons have been created by compartmentalization of the original 'lagune de Melgueil' starting from the late $17^{\text {th }}$ century due to building of the Canal de Rhône à Sète, canalization of the Lez River, and later by building roads to gain access to the beaches. The main WWTP of the Montpellier agglomeration is located on the coastal plain between the city and the lagoons and close to the Western shore of the Lez River. The original WWTP, which was called La Cereirede, discharged its nutrient-rich effluents directly into the Lez River. As a result, the Méjean, Grec, Prévost and Arnel lagoons have been particularly impacted by the nutrient overenrichment, while the Ingril lagoon, further away, has been less impacted (Ifremer, 2007). Thanks to the new WWTP facility MAERA with its offshore outfall system located at $11 \mathrm{~km}$ from the coast (Figure 1), all seven have benefited at the same time from reduction of their nutrient loading. This represented a unique opportunity, as the seven lagoons of the Palavasian complex represented a clear eutrophication gradient in 2005 (Ifremer 2007) it is possible to asses how ecosystem trajectories during restoration are influenced by the prior eutrophication state of the system. Hence, for this study the Méjean lagoon and the Ingril lagoon were selected as specific cases, representing a hypertrophic and a less impacted lagoon, respectively. Méjean lagoon has a surface of $5.6 \mathrm{~km}^{2}$ and an average depth of $0.73 \mathrm{~m}$ and belongs to the municipalities of Lattes and Pérols. Salinity fluctuates between 10 and 30 with some occasional values of 5 after heavy rainfall. Ingril lagoon has a surface of $6.2 \mathrm{~km}^{2}$ and an average depth of $0.66 \mathrm{~m}$ and is separated into two parts by the Canal de Rhône à Sète. 


\section{METHODS}

\section{Discussion of ecosystem trajectories by a focus group and proposals for active restoration}

The major difficulties in this study were to obtain a comprehensive view of ecosystem restoration and the different management issues and share the language and methods between ecologists and socio-economists. The collective approach that was adopted is depicted in Figure 2 and described in detail below.

Most ecologists are specialists in a certain field, e.g. microbial ecologist, botanists, benthologists, ornithologists, and none of them has a comprehensive view of the restoration of lagoon ecosystems. Therefore, it was important to bring these experts around a table, to share their views with the authors of this paper ( 3 ecologists, 2 socio-economists) and provide expert judgement in a collective and integrative way. Hence, 15 experts in ecology were invited, of which seven actively participated in a focus group meeting organized on 15 May 2013 at the University of Montpellier (see Table S1). Those experts unable to participate in the meeting were visited afterwards.

To structure the discussion with the specialists it was decided to predict the ecosystem restoration trajectories by using selected ecosystem state variables. Hence, clear hypotheses were formulated and based on these hypotheses the trajectories were predicted. As an input, the experts used their general knowledge of the scientific literature and were provided access to the data collected within the frame of the "Réseau de Suivi Lagunaire" (RSL) monitoring programme, which was operated from 2000-2013 by Ifremer, The Regional Council of the Languedoc-Roussillon Region and The Agence de l'Eau RhôneMéditerranée-Corse (Ifremer, 2002, 2005, 2007, 2010, 2013, 2014; "Réseau de Suivi Lagunaire" (RSL), 2014). It focused on monitoring the ecosystem state of the lagoons with respect to eutrophication; every year, i.e. during summer the water chemistry (concentrations of $\mathrm{NO}_{3}{ }^{-}, \mathrm{NO}_{2}{ }^{-}, \mathrm{NH}_{4}{ }^{+}, \mathrm{PO}_{4}{ }^{3-}$, total dissolved and suspended nitrogen $\mathrm{TN}$ and total dissolved and suspended phosphorus TP), and Chlorophyll a concentrations, as a proxy for phytoplankton biomass, have been measured. In addition, macrophytes (both macroalgae and Magnoliophyta) and sediment features (total $\mathrm{N}$ and $\mathrm{P}$ contents in the top 5 $\mathrm{cm}$ and granulometry) have been monitored every three and six years, respectively. Reported observations between 2006 and 2012 (Ifremer, 2007, 2010, 2013) were used to confront predictions with reality. Predictions at longer decadal scales, i.e. expected to occur after 2012, could obviously not be tested. In addition, some formal biodiversity inventories (Direction Régionale de l'Environnement, de l'Aménagement et du Logement, DREAL, de la Région Languedoc-Roussillon, 2010) were used for this comparison, as well as the Masterplan (DOCOB) of the Natura 2000 site (see Figure 1) and other specific reports prepared by the Syndicat mixte des étangs littoraux (2009 a, b, 2010). The predictions are presented graphically and are discussed critically for each ecosystem variable. This approach was, however problematic for the socio-economic colleagues, who suggested that the information should be presented on a conservation quality scale and the ensemble of the ecosystem state variables should be aggregated in a single attribute that could be understood in terms of 'biodiversity' or 'environmental quality' by the general public. As a first approach, it was decided to conceptually rescale the selected ecosystem variables along a scale ranging from bad $(B)$, poor $(P)$, moderate $(M)$, good $(G)$ and high $(H)$ as is currently 
used for the RSL and WFD monitoring programmes. In practice this meant that ecosystem state variables where high values indicate low environmental quality, as e.g. the biomass densities of phytoplankton and opportunistic macroalgae were inverted on the graphic ordinate to range from high value (poor quality) to a low value (high quality). Other state variables, where high values corresponded to high quality, as e.g. the extension of marine Magnoliophyta meadows were represented on the ordinate as usual. The aggregation of these variables for a single attribute was decided collectively and the process is described in the section below.

\section{Multiple contingent valuation and preparation of a questionnaire}

The economic valuation was based on contingent valuation, which belongs to the "stated preference" methods. In a standard contingent valuation (CV), only a single scenario is exposed to the public that is compared to a reference situation (e.g. Ahtiainen et al., 2013) and respondents are asked for their acceptance and willingness to pay for the scenario. The format recommended for the questionnaire is a type of referendum, one prior cost being associated to the unique scenario. The outcome of the survey is then a distribution of willingness to pay for that scenario. As a consequence, the results do not support variations in restoration beside the main scenario, nor do they give any empirical evidence about the weight of a project's characteristics in the preferences of respondents. To overcome these limitations, a CV survey with four scenarios was designed, in order to obtain more variability in the project's attributes and, thus be able to estimate their impact on the acceptability and the WTP of respondents. The actual questionnaires were designed largely based on the results from the focus group (cf. Figure 2) that are described in the Result section. Considering two attributes, i.e. i) biodiversity (an aggregation of different ecosystem state variables), and ii) socio-economic issues, and three levels for each attribute, results in nine possible combinations. Out of these, four combinations were selected to present at the same time contrasting situations with realistic combinations (see Results for choice). This approach, which is intermediate between a standard contingent valuation and a choice experiment, is referred to as a multiple contingent valuation (MCV).

The Hérault department has a total population of 1.1 million inhabitants of which about 450000 live in the urban agglomeration of Montpellier, including 265000 inhabitants of the municipality of Montpellier. In addition, during summertime the Mediterranean coastline of the lagoons is an important tourist destination with Palavas and FrontignanPlage as the main holiday resorts. Therefore, two different versions of the questionnaires were prepared, i.e. for residents and tourists, respectively. The questionnaires were designed in four modules and were presented to the interviewees in two steps. First, questions focused on the origin of the respondents and the modes and frequencies of them using the lagoon. The survey included questions that checked respondents' perceptions and how they valued the different ecosystem services of the lagoons as per three of the four main types used in the Millennium Ecosystem Assessment (2005). As the study targeted the general public rather than specific user groups, like professional fishermen or hunters, provisioning services were excluded. Subsequently, using graphic illustrations (Appendices S1 and S2), the context was presented to the respondents comprising geographic information and uses of the lagoons. The interviewer presented the four selected scenarios for active ecosystem restoration for the Méjean lagoon. The other modules were focused 
respectively on willingness to pay and accompanying questions on the perception and main societal issues, and the socio-economic characteristics of the respondents. Face-to-face interviews were carried out during July and August 2013 in three different municipalities, i.e. Montpellier (Esplanade de l'Europe and close to the railway station), Lattes (central plaza in town) and Palavas les Flots (on the sea beach). On average, the duration of the interview was about 20 minutes.

\section{RESULTS}

\section{Description of the ecosystem state since $\mathbf{2 0 0 0}$ and developments until 2013 for the lagoons of the Palavas complex}

At the beginning of the $21^{\text {st }}$ century, the seven lagoons of the Palavas complex showed a clear eutrophication gradient and the RSL quality scores were systematically better in the south-west than in the north-east. For example, between 2001-2006, the scores in Ingril lagoon fluctuated between Poor and Moderate with occasionally Good scores, while Méjean lagoon presented systematically Bad quality scores (Réseau de Suivi Lagunaire, 2014). The experts decided to focus their analyses on these two contrasting lagoons.

The annual monitoring during summer periods showed that phytoplankton densities responded very quickly to the reduction of nutrient inputs after 2006. Hence in Méjean lagoon, summertime Chla concentrations in the water column fluctuated between 100 and $400 \mathrm{mg} \cdot \mathrm{m}^{-3}$ before 2006, and afterwards dropped by one to two-orders of magnitude to fluctuate between 1 and $25 \mathrm{mg} \cdot \mathrm{m}^{-3}$. The phytoplankton community in this lagoon was dominated by diatoms and green microalgae. In Ingril lagoon, before 2006 the summertime Chla concentrations fluctuated between 5 and $20 \mathrm{mg} \cdot \mathrm{m}^{-3}$, and afterwards between 0.6 and 3 $\mathrm{mg} \cdot \mathrm{m}^{-3}$.

At the start of the lagoon monitoring by the RSL in 2000, no meadows of Magnoliophyta occurred in the Méjean lagoon, and up to 2012 only relicts have been observed in the form of very small patches (Direction Régionale de l'Environnement, de l'Aménagement et du Logement (DREAL) de la Région Languedoc-Roussillon, 2010). Extended macrophyte surveys have been realized for the Méjean lagoon at 13 stations (i.e. 7 in the western and 6 in the eastern part) in 2001, 2004, 2006, 2009, and 2012. For all of these surveys, Magnoliophyta were never observed, while the first three surveys (2001, 2004 and 2006) showed virtually no (i.e. $<0.5 \%$ of coverage of the lagoon bed) macroalgae (Ifremer, 2002, 2005, 2007). In contrast, the surveys in 2009 and 2012 showed lagoon bed coverages of macroalgae of $44 \pm 37 \%$, and $49 \pm 39 \%$, respectively (Ifremer, 2010, 2013). The dominant populations included Ulva spp. and Chaetomorpha spp. and more occasionally the red alga Chondria capilaris that during the summer in 2009 covered about $30 \%$ of the lagoon bed in the eastern part.

During the early 2000s Ingril lagoon did not contain well-developed Magnoliophyta prairies, although some patches of Ruppia sp. occurred before 2006. Between 2006 and 2012 a recolonization of the Magnoliophyta prairies was observed. By 2012 in the southern part of the Ingril lagoon there were dense but sparsely distributed meadows covering about one third of the sediment surface. Zostera noltei was the main species although at several 
stations it coexisted with Ruppia cirrhosa (Syndicat mixte des étangs littoraux (SIEL) and P2A Développement SARL, 2012).

The sedimentary concentrations of total $\mathrm{N}$ and total $\mathrm{P}$ in the top $5 \mathrm{~cm}$ at the monitoring stations in the Palavasian lagoons between 1999 and 2012 are shown in Figure 3. Among the stations from the seven lagoons, the western station in the Méjean lagoon contained the highest concentrations of $\mathrm{N}$ and $\mathrm{P}$, around $4 \mathrm{~g} / \mathrm{kg}$ and $0.9 \mathrm{~g} / \mathrm{kg}$, respectively. The southern station in the Ingril lagoon contained the lowest values of around $1-2 \mathrm{~g} / \mathrm{kg}$ and $0.4 \mathrm{~g} / \mathrm{kg}$ for $\mathrm{N}$ and $\mathrm{P}$, respectively. The eastern station in Méjean lagoon was intermediate between these extremes for both $\mathrm{N}$ and $\mathrm{P}$ values. The northern station in Ingril lagoon was as low in $\mathrm{P}$ as the southern station in this lagoon, but recorded a higher level of $\mathrm{N}$, i.e. around $3 \mathrm{~g} / \mathrm{kg}$ (Ouisse et al., 2013).

\section{Hypothesis and predicted ecosystem trajectories for the Méjean and Ingril lagoons}

The focus group agreed on the four following hypotheses:

H1- Phytoplankton densities respond very quickly to a decrease of the external $\mathrm{N}$ - and Ploading to the lagoon.

$\mathrm{H} 2$ - Lagoon sediments that have been historically enriched in $\mathrm{N}$ and $\mathrm{P}$ during the eutrophication phase will show a net efflux of $\mathrm{N}$ and $\mathrm{P}$ from the sediment during the reoligotrophication phase. The total $\mathrm{N}$ and $\mathrm{P}$ contents of the sediment are the main drivers for these $\mathrm{N}$ and $\mathrm{P}$ effluxes, respectively. As a result of these effluxes, the sediments will progressively decrease their $\mathrm{N}$ and $\mathrm{P}$ content during re-oligotrophication.

H3- Opportunistic macroalgae benefit from a decrease of phytoplankton in the water column as this results in higher light availability; since these macroalgae are located on average closer to the sediment surface than phytoplankton, they may benefit from $\mathrm{N}$ and $P$ release from the sediment.

H4- Recovery of marine Magnoliophyta can occur as a spontaneous process, when these plants are released from competition for light with both phytoplankton and macroalgae. The recovery rate may, however, be limited by a low availability of seed banks in the lagoon and by a low connectivity with potential source populations in nearby lagoons.

Predicted ecosystem trajectories based on these hypotheses and considering the different states of the two lagoons before the reduction of the nutrient loading are shown in Figure 4. For the less impacted Ingril lagoon, it was predicted that Magnoliophyta would be able to recolonize the lagoon concomitantly with a decrease in phytoplankton biomass densities and decreasing $\mathrm{N}$ and $\mathrm{P}$ contents of the sediment. A process in two-phases was described based on the prediction that ecosystem restoration in the northern part of Ingril would lag behind that occurring in the southern part. For this lagoon, it was predicted that the densities of opportunistic macroalgae would remain low. Except for phytoplankton trajectories, a very different chronology was described for the highly impacted Méjean lagoon. Thus, it was predicted that marine Magnoliophyta would not be able to colonize the 
lagoon for a very long time, concomitantly with a very slow rate of improvement of the quality indices for the sediment. While the phytoplankton quality index was expected to improve rapidly after the reduction of the external loading, following hypothesis $\mathrm{H} 3$, it was predicted that opportunistic macroalgae would increasingly proliferate. The monitoring observations in 2009 and 2012 indeed showed the appearance of macro-algae during the early stage on the Méjean trajectory after reduction of nutrient loading (see above). The abundance of the macroalgae was considered as characteristic for a transient phase, while macroalgal densities were expected to fluctuate strongly within and between years. After some time, however, it was expected that the lagoon would leave the transient state when concomitantly with an accelerated improvement of the sediment and the water column DIN and DIP quality indices, the macroalgal densities would decrease systematically. This would allow the colonization by the Magnoliophyta and move towards the final ecologically restored state. Nevertheless, it is still difficult to predict the duration of the macroalgaldominated transient state.

The focus group also evaluated the impact of these different trajectories on avifauna. Hence, it was predicted that the colonization of the lagoon by the Magnoliophyta would be beneficial for herbivorous and piscivorous bird species, e.g. ducks and herons, respectively. In contrast, greater flamingos (Phoenicopterus roseus) use non-vegetated sediments for foraging and were, therefore, expected to decrease in number within the lagoons with increasing coverage of Magnoliophya.

\section{Active restoration as an option for conservation management in the Méjean lagoon and the impact on its ecosystem trajectories}

The high coverage of macroalgae observed during the surveys in the summers of 2009 and 2012 (see above, cf. Fig 4) was highlighted as an interesting phenomenon and it was recommended to make use of it during the first part of the restoration process. Hence, harvesting the macroalgae and extracting them from the lagoon will export the $N$ and $P$ contained in their biomass from the lagoon. Once, the good conditions for Magnoliophyta growth are established again it can be expected to further accelerate the process by seeding and or transplantation. The broken lines in Figure 4 depict the impact of the additional measures on the trajectories of the different variables in Méjean lagoon. The quality indices associated to most of the ecosystem variables show an acceleration of their improvement, with the exceptions of the negative impact on greater flamingos and an almost negligible impact on phytoplankton. The experts were, however, not able to predict the length of the macroalgal-dominated transient phase, neither for the passive and active ecological restoration trajectories.

\section{Consensus and controversy among the experts}

There was a remarkable degree of consensus among the experts concerning the predicted trajectories (Figure 4), although as mentioned above, most experts highlighted that, the time-scale of the processes are still difficult to assess. It requires obtaining the experience in the field combined with careful monitoring of a couple of case studies. Otherwise estimates could be derived from ecosystem modelling using a coupled 
biogeochemical-ecological model. On the other hand some controversies arose among the experts.

Firstly, there was controversy about the reference state chosen as the target for a desired state of the ecosystem. In the Ayrolle lagoon the $Z$. noltei coverage typically exceeds $80 \%$ of its lagoon bed, and this lagoon has often been used as a reference site for these Mediterranean lagoons (Ifremer, 2014). While comparable in mean depth (i.e. Méjean lagoon $0.73 \mathrm{~m}$, Ingril lagoon $0.66 \mathrm{~m}$, Ayrole lagoon $0.64 \mathrm{~m}$ ) it is believed that besides eutrophication levels there are numerous other physical differences between the lagoons that mean it is not appropriate to adopt the Ayrole lagoon as a reference site.

A second controversy related to the techniques of transplanting the Magnoliophyta. Some argue that proliferation of the plants simply depends on the ecological conditions and if these conditions are fulfilled the Magnoliophyta will proliferate regardless. In contrast, when the ecological conditions are not fulfilled, transplantation is generally unsuccessful and plants die within a few months, thus it is a waste of money developing such techniques. Others agreed to warn against trying to transplant or seed when conditions are clearly unfavourable, but, nevertheless, recognized that this maybe a useful technique when conditions have improved in systems where plants earlier have existed and where their proliferation may be limited due to depletion of the seed banks and these are too large distances (connectivity) from potential source population.

A third controversy was generated about the concept of 'iconic', 'charismatic' or 'emblematic' species when communicating with the public. Emblematic is the term most commonly used in France. It is most important to use emblematic species when introducing the questionnaire to the general public and ask for their participation as these emblematic species make the subject more easily recognizable for them. However, the concept of emblematic species may be confounded with the concept of patrimonial species, a concept often used by French practitioners of nature conservation and environmental management. It is also important to aggregate variables to create a limited number of attributes for the questionnaires. Hence, it was proposed to take the surface coverage of Magnoliophyta in the lagoon as exemplary of an ensemble of ecosystem variables including avifauna and fishes, particularly the presence of seahorses (Hippocampus guttulatus). Some experts doubted whether $H$. guttulatus could recolonize all the lagoons and underscored that such a process depended on connectivity with source populations and on ecological conditions in the lagoon, e.g. salinity fluctuations.

\section{Design of the questionnaire for the Multiple Contingent Valuation}

Based on the preparatory work of the focus group and interviews with other specialists it was concluded that the least impacted lagoon Ingril is already on a satisfactory trajectory for ecosystem restoration and, therefore, no additional measures have been recommended. In contrast, additional measures were recommended for active restoration for the most impacted lagoon Méjean and, therefore, the socio-economic study was focused on this lagoon only (cf. Figure 2). The attribute 'biodiversity' (see methods) was created based on an aggregation of several ecosystem variables ( $c f$ Figure 4 ) that were represented by the surface coverage of Magnoliophyta in the lagoon. The surface coverage of 
Magnoliophyta is positively linked with good quality indices for water column and sediment and biodiversity as exemplified by herbivorous and piscivorous birds (see Figure 4) and by fishes (including the emblematic Hippocampus guttulatus, see above). Hence, surface coverage of Magnoliophyta is a good proxy for good ecological conditions in coastal lagoons (sensu WFD) and indeed also reflects a high degree of biodiversity. Nevertheless, the negative trade-off between surface area of Magnoliophyta and foraging greater flamingos (see above, cf. Fig. 4) was explicitly taken into account and clearly presented to the interviewees. Hence, the three levels for the surface coverage of Magnoliophyta in the lagoon were described for the interviewees as follows:

1) Status quo: 0 to $10 \%$ Magnoliophyta coverage implying high numbers of flamingos foraging in the lagoon, no swans, no emblematic seahorses (Hippocampus guttulatus), and bad water quality indices

2) $40 \%$ Magnoliophyta coverage implying intermediate numbers of flamingos foraging in the lagoon, no swans, but some herbivorous duck species, e.g. Eurasian wigeon (Anas penelope), low number of emblematic seahorses (Hippocampus guttulatus), and water quality indices improved;

3) $70 \%$ Magnoliophyta coverage or higher implying a large decrease in the numbers of flamingos foraging in the lagoon, high number of swans and herbivorous duck species, e.g. the Eurasian wigeon (Anas penelope), high number of emblematic seahorses (Hippocampus guttulatus), and a good to high quality status for the water quality indices.

Public policy often aims to accompany conservation and ecological restoration measures with increasing access to the site. Currently, cycling paths follow the western shoreline $(4 \mathrm{~km})$ and a small section $(0.5 \mathrm{~km})$ of the easternmost shoreline of the lagoon, while footpaths have been created through the peripheral marshes bordering the NW sector of the lagoon. Hence, more footpaths could be created to increase accessibility to the site, while at the same time care should be taken that hikers do not disturb the waterfowl. Therefore, access to the site was added as an additional attribute and based on this attribute, three different options for spatial planning of the access have been proposed:

1) Status-quo for this attribute: maintenance of the existing walking and cycling paths as the only access to the zone;

2) Increase the number of footpaths, but without hides and other additional measures to reduce the disturbance of waterfowl by hikers;

3) Increase the number of footpaths, combined with hides and other additional measures to reduce the disturbance of waterfowl by hikers.

The two different versions of the questionnaire, for residents and tourists, are provided in Appendix S1 and Appendix S2, respectively, with their illustrative material used in interviews. From the nine possible combinations four were selected (see Methods) comprising:

I -Magnoliophyta level 1, footpaths level 2 (scenario 1 - M1-F2) 
II -Magnoliophyta level 2, footpaths level 1 (scenario 2 - M2-F1)

III -Magnoliophyta level 2, footpaths level 3 (scenario 3 - M2-F3)

IV -Magnoliophyta level 3, footpaths level 3 (scenario 4-M3-F3)

\section{Descriptive statistics of the sample}

One hundred and fifty-nine interviews were conducted, comprising 94 residents and 65 tourists. The socio-economic profile of the sample is shown in Table 1, and Tables S2 and S3. Gender distribution was quite equilibrated with males slightly overrepresented and representing $52 \%$ and $54 \%$ for the residents and tourists, respectively. Among the residents, the age class $18-30$ years was most represented by about $40 \%$, although it was slightly lower than for the urban area of Montpellier altogether (43.6\% see Table 1 ).

\section{Attitudes, perceptions and recreative uses of lagoons}

Forty percent and $69 \%$ of the residents and tourists, respectively, replied that they do not visit the lagoons. Among the users, walking, bird watching and enjoying nature was the major recreational activity pursued by $47 \%$ and $23 \%$ of the resident and tourist respondents, respectively. Cycling was also popular, representing $31 \%$ and $15 \%$ of the resident and tourist respondents, respectively; while nautical sports, horse and pony trekking, and fishing were the other main activities. Several respondents indicated that they pursued multiple activities, which is reflected by a total sum of activities exceeding $100 \%$ Table 2).

Among the non-users, the fact that they were unfamiliar with the lagoons was most often invoked, representing $26 \%$ and $58 \%$ of the residents and non-user tourists, respectively. There was a more equal distribution of responses among resident non-users compared to tourists. The total of responses summed slightly above $100 \%$ indicating a very limited number of multiple responses (Table 3). Among the interviewed residents, it was observed that the residents born in the Languedoc-Roussillon region visited the lagoons more frequently than residents born in other regions.

The supporting service provided by biodiversity was identified most often as the most important ecosystem service provided by the lagoons, i.e. by $52 \%$ and $60 \%$ of the resident and tourist respondents, respectively (Table 4). More than $80 \%$ of both groups recognized this service among the top two priorities. The second largest group identified the regulating services as the top priority. Only about $10 \%$ of both resident and tourist respondents considered cultural services as the top priority, nevertheless, a large proportion indicated these as the second priority. As a result about the half of the resident and tourists respondents recognized cultural services among the top two priorities for lagoons. In addition, a very large majority, i.e. $87 \%$ and $85 \%$ of residents and tourists, respectively, fully agreed with the statement "the lagoons represent an important natural heritage asset and should be conserved for future populations" and entirely disagreed with the statement that "it is useless to restore the ecosystems as sooner or later these will disappear due to sea- 
level rise". A slightly smaller proportion, i.e. $80 \%$ and $68 \%$ of residents and tourists, respectively, entirely disagreed with the statement that "there is too much priority for restoring lagoon ecosystems compared to other societal issues".

\section{Preferences for scenarios and willingness to pay.}

Among the respondents, $77 \%$ and $71 \%$ of the residents and tourists, respectively preferred scenario 4, which combines the highest degree of ecosystem restoration (M3) with construction of additional footpaths, combined with hides and other additional measures to reduce the disturbance of waterfowl by hikers (F3). Sixty-six (70 \%) and forty-three (66 \%) interviewed residents and tourists, respectively, explicitly confirmed their willingness to contribute financially to an active restoration programme for the Méjean lagoon (Table 5). This proportion is lower than the above-mentioned $85 \%$ of respondents that recognized the need for ecosystem restoration. The main reasons why respondents were reluctant to contribute financially were because either, i) they are not willing to pay additional taxes (17 $\%$ and $26 \%$ of residents and tourists, respectively), or ii) thought that it was not their responsibility to pay for the restoration ( $11 \%$ and $5 \%$ of residents and tourists, respectively) (Table 5). A small proportion were not confident and doubted whether their financial contribution would be effectively allocated to the restoration of the Méjean lagoon and were suspicious that it might be used for other public spending. WTP for the four different options is highly variable both among residents and tourist as shown by the frequency distributions depicted in Figs 5 and 6, respectively. Nevertheless, the highest mean and median values were observed for scenario 4 , which is coherent with the preferences expressed by the respondents.

\section{Data processing and econometric estimation of Willingness to Pay}

From the 159 questionnaires, we get $159 \times 5$, e.g. 795 responses for Willingness to Pay (WTP) corresponding each to a specific combination of levels of the restoration of Magnoliophyta prairies and access facilities. To take advantage of the multiple scenarios valuation, 5 scenarios were considered, i.e. the four studied scenarios as well as a Business as usual (BAU) scenario, which corresponds to (M1-F1) plus). These 5 scenarios were coded as a combination of dichotomous variables, and the individual data were duplicated five times to get a panel structure (hence for each respondent we obtained 5 values for WTP, one for each scenario).

Before proceeding to econometric estimation, some questionnaires were discarded as follows. It was observed that 20 questionnaires have the same positive WTP for the 4 scenarios, while 11 respondents provided four null values. This expresses a strategic bias, either in favour or against the restoration. The answers were crosschecked against the two questions "I would not pay an additional tax" and "It's not my duty to pay for the restoration" (Table 5). In the first case, the refusal is clear, and even if the respondent provided a value for a scenario, that is not a real WTP. In the second case, the given value expresses the value given to the scenario, to be paid by someone else, but not the own WTP of the respondent. Eventually, 24 questionnaires were discarded for Residents and WTP estimation proceeded with 70 respondents (e.g. 350 observations). The same procedure was used for the Tourists, thus obtaining 45 valuable respondents and 225 observations (cf. 
Fig 5 and Fig. 6, showing the frequency distributions for the four different scenarios of the WTP for residents and tourists, respectively).

The monetary variables related to the level of ecosystem restoration (roughly WTP) increase with the level of seagrass bed restoration, ranging from $€ 11.3$ up to $€ 29.45$ per year, and from $€ 3.37$ up to $€ 10$ per week, for residents and tourists, respectively (cf. Table S4 for detail on econometric calculations). Estimates do not exhibit any trade-off in preferences between the biodiversity state attached to low and high level of restoration. The variable for income is low, not significant for residents, but significant for tourists. WTP increases with age, more so for tourists than for residents. Variable estimates are used to compute the average WTP by the residents: for a high level of restoration (M3) the WTP is €25.00 per year, for a medium level of restoration (M2) it is €16.58 per year, and for a low-level (M1) it is €6.55 per year. The WTP for creating additional footpaths and hides for observing birds without disturbing them was much lower, i.e. only $€ 5$ per year. Some respondents replied that such new structures would damage their perception of 'naturality' of the site and thus jeopardize their feeling of enjoying nature.

\section{DISCUSSION}

\section{Ecological restoration as part of the conservation management of coastal lagoons}

In this study, a framework for a transdisciplinary study has been developed for addressing the ecological and socio-economic issues of the ecological restoration of coastal lagoons (see Figure 2) through a collective learning process. A focus group was used to synthesize the pertinent ecological knowledge and develop future prospective for ecosystem trajectories. A study on the restoration ecology of Berre lagoon (S. France) also used a focus group, which aim was to characterize the natural capital of the historical reference states and achieve consensus for selecting one of them as a model for the desired state of this specific lagoon (Aronson et al., 2012). In this study, the focus group was used to rationalize the thinking about possible future ecosystem trajectories.

The ecological restoration of coastal lagoons is still in its infancy compared to that for freshwater lakes. However, in both cases, the improvement of water transparency and return of SAV are often the major objectives, particularly when the objective is to revert the eutrophication process that can be considered as a re-oligotrophication. For lakes the potential role of the sediments in retarding restoration has been underscored (Eppesen et al., 2005) and this phenomenon also appears to be relevant for coastal lagoons. A remarkable degree of consensus existed among the experts for predicting the sequence of events during re-oligotrophication (see Figure 4), although it has to be highlighted that the time scale of this process is subject to a very high degree of uncertainty. More detailed studies on the biogeochemistry and hydrodynamics of the lagoons are required and a coupled ecological-biogeochemical-hydrological model could provide the basis for more quantitative predictions concerning the time frame. Nevertheless, the six years of summer observations since the nutrient reduction provided support for hypothesis $\mathrm{H} 1$ (decrease of phytoplankton densities in both lagoons) and partial support for $\mathrm{H} 2$ (cf. Fig. 3, Ouisse et al., 2013 ) in both lagoons. However, based on splitting the sediment samples into two groups, i.e. sediment samples before 2006 and between 2006-2012, respectively, a predicted 
decrease in $\mathrm{N}$ and $\mathrm{P}$ content due to benthic fluxes was not statistically significant (Welch test, $p>0.05$ for total $N$ and total $P$ in both Ingril and Méjean lagoons, $n=13$ ). The low frequency of observations may explain that such a predicted trend is not yet visible. Partial support for H3 (appearance of macroalgae during a transient state) and H4 (spontaneous recovery of Magnoliophyta) were obtained for Méjean and Ingril lagoons, respectively. In Ingril lagoon, observations of increasing Zostera noltei and Ruppia chirrosa meadows are in agreement with predictions ( $c f$. Fig. 4) that return of Magnoliophyta may be a fast process for lagoons that have been impacted by eutrophication to a lesser degree only. Although, future scientific studies should be focussed on testing the general validity of the hypothesis $\mathrm{H} 1-\mathrm{H} 4$ forwarded in this study.

Hence, it clearly appears that for lesser-impacted lagoons, e.g. Ingril lagoon, a return to good ecological conditions may occur spontaneously and quite rapidly following the reduction of nutrient loading. In contrast, ecological restoration of the Méjean coastal lagoon without any further additional measures would take a very long time, probably decades (Ouisse et al., 2013). Thus, while reduction of nutrient loading is of paramount importance in all cases, ecological restoration within a reasonable time frame of the more heavily impacted lagoon requires additional measures, which is characterized as active restoration (see Introduction).

Additional measures may thus speed up the restoration project in Méjean lagoon and a draft for an active restoration project has been designed that comprises two steps. The first step entails macroalgal removal. In the past, removal of Ulva spp. has been used to combat the symptoms of severe eutrophication and prevent dystrophic crises in the nearby Prévost lagoon (Guyoneaud et al., 1998). Macroalgal growth close to the sediment surface will intercept DIN and DIP effluxes from the sediment (hypothesis $\mathrm{H} 3$ ) and thus contribute to lower DIN and DIP concentrations in the water column. During 2012, benthic effluxes of 3-6 $\mathrm{mmol} \mathrm{N} \mathrm{m}{ }^{-2}$ day $^{-1}$ and 0.05 to $0.5 \mathrm{mmol} \mathrm{P} \mathrm{m}^{-2}$ day $^{-1}$ have been measured in the Méjean lagoon (Ouisse et al., 2013). By increasing the concentration gradient from the sediment to the overlying water it appears very likely that macroalgal growth will increase the driving force for the benthic efflux of $\mathrm{N}$ and $\mathrm{P}$ from the sediment. Hence, macroalgal growth could accelerate the decrease of the total $\mathrm{N}$ and $\mathrm{P}$ contents of the sediment in a sustainable way, provided that its biomass is exported from the lagoon. The results of the first phase of the active restoration management need to be monitored in order to decide when it becomes appropriate to start the replanting or seeding of the Magnoliophyta. However, there was no general concensus for actively planting of Magnoliophyta. In general, it was agreed that after a transient state, whence there is a simultaneous increase of the quality indices for the water column DIN and DIP and the total N and P contents of the sediments, conditions may become favourable for recolonization by Magnoliophyta. A recent opinion paper based on experiences throughout Europe confirms that priority should be given to enhancing the natural restoration potential for seagrass habitats (Cunha et al., 2012). A fictive ecological restoration project was proposed for Méjean lagoon in order to provide an understandable context for the socio-economic questionnaires. According this project, removal of macroalgae from the lagoon would be pursued for a period of 5 years. The planting or seeding of the selected Magnoliophyta would start only after this first 5-year period and be pursued for an additional period of 5 years. Thus, the total period of this fictive project proposed to the interviewed public would be equal to 10 years, which was considered as 
sufficiently short for the public to feel themselves concerned by the project and willing to contribute to this study.

Active restoration designed with the original aim of improving the water quality is clearly compatible with a proactive conservation strategy. Increasing Magnoliophyta meadows in coastal lagoons, in addition to its positive impact on water quality, will promote an increase of herbivores and piscivorous bird species (ducks e.g. Anas penelope; swans, e.g. Cygnus olor; and herons Egretta garzetta and Ardea cinerea), and several fish species would also increase in abundance. Fish assemblages associated with Z. noltei meadows in the closeby Thau lagoon have been described in Villégier et al. (2012), which include sygnate Sygnathes abaster and the emblematic Hippocampus guttulatus. On the other hand, the disappearance of non-vegetated sediments at the expense of Magnoliophyta meadows has a negative impact for greater flamingos (Phoenicopterus roseus), which sieve the bare sediment to collect small macrofauna. The latter are emblematic species in south France, regularly 800 individuals have been observed in the Méjean lagoon. While, the latter shows that not all species will benefit from the ecosystem changes during restoration, in general it seems reasonable to use Magnoliophyta coverage as an aggregate attribute in socioeconomic studies as it is a proxy for many biodiversity values. In addition, it correlates with a high level for the water quality index and is thus useful for searching a convergence between objectives for conservation (e.g. Habitat directive) and water quality management (WFD).

\section{Perceptions by the residents and tourists of ecological restoration of lagoons and econometric estimation of their Willingness to Pay for it}

In this study, the 159 interviews represented satisfactory sample sizes for this pilot study, particularly for testing the new approach described in Fig. 2. Nevertheless, the size of the samples is not sufficient for use as support in public policy development as more statistic precision would be needed and possible bias should be prevented. In this respect, the sample of the interviewed residents corresponded quite well to the socio-economic profile censed for the inhabitants of the urban area of Montpellier except that unemployed and students were overrepresented with respect to intermediate and high level employees (cf. Tables 1 and S2). Such a check is, however, not possible for the sample of the tourists. Nevertheless, in the context of our novel approach (cf. Fig. 2) it has been possible to put human perceptions and WTP in perspective with a scientific expert analysis of lagoon ecological status and trajectories and how these respond to passive or active ecological restoration. Based on several provocative questions, it was concluded that among the interviewed residents and tourists above $85 \%$ have positive perceptions both of the ecological and societal importance of coastal lagoons as well as of the ecological restoration of ecosystems, and particularly the ecological restoration of the lagoons. The high perception of the ecological and societal importance of lagoons appeared to be based mainly on the recognition by the respondents of the importance of supporting and regulating ecosystem services in coastal lagoons. Their cultural ecosystem services were also highly appreciated by a minority, mainly for walking, leisure and enjoying landscape (cf. Table 4). The fact that this was a minority only probably reflects that high proportions of residents and tourists, $40 \%$ and $69 \%$, respectively, did not use the lagoons for their own leisure activities (cf. Table 3). 
Hence, there was general support for the active ecological restoration proposed for Méjean, which implies specific management actions in addition to the $150 \mathrm{M} €$ invested in 2005. This large sum was invested for improving the Montpellier WWTP and reaching a strong reduction of nutrient loadings to all seven lagoons of the Palavas complex. The public support is reflected by the $70 \%$ and $66 \%$ of the residents and tourists respondents, respectively, which declared to be willing to contribute financially for the ecological restoration of lagoons. However, this is lower than the above $85 \%$ of respondents that recognize the importance of coastal lagoons and the need for their ecological restoration. The difference was explained by the fact that some are reluctant to pay (cf. Table 5). WTP was quite variable, more so within the sample of the residents than among the interviewed tourists. However, the clearly stated preference for scenario 4 was coherent with the highest median and mean WTP values (cf. Figs 5 and 6). This latter scenario was based on achieving the highest level for Magnoliophyta meadows. The ecological restoration of Magnoliophyta meadows is indeed favourable for biodiversity in general, although not all emblematic species will benefit from it. Nevertheless, the trade-off of Magnoliophyta for greater flamingos, which was clearly indicated to the respondents, appeared to play no role in their response. It is possible that the respondents did not perceive this trade-off or that the other aspects of biodiversity were considered to outweigh it.

Hence, it was really instrumental for this study to propose the four different scenarios and submit each to a classical contingent valuation to collectively become a multiple contingent valuation (MCV). To the best of our knowledge, this is the first study to apply such a MCV. By asking for multiple responses, we obtained a panel structure for the two project attributes, comprising 350 and 225 observations, for residents and tourists, respectively. With such a panel the impact of project attributes and individual characteristics on the WTP were assessed, as in a choice experiment (cf. Hanley, 2001 for a comparison of a choice experiment with contingent valuation). The results were statistically robust (cf. Table S4) and showed for the resident respondents a WTP of about 25 euros per year for the highest level of ecological restoration, while they were only willing to allocate about 5 euros per year for additional footpaths and hides. Hence, the residents, but also the tourists, clearly showed a higher sensibility towards ecosystem quality and were less interested in improving access for hiking and bird-observations. Some of them even disapproved such infrastructure.

Hence, the survey showed that a strong support exists for active ecosystem restoration among the residents from the Montpellier urban area and the tourists. Hence, for the most impacted lagoons, in addition to the $€ 150 \mathrm{M}$ investment that was necessary to relieve the overenrichment pressure, it makes sense to develop an active ecosystem restoration management strategy as part of a conservation plan for these coastal lagoons. In general, while reduction of nutrient loading is of paramount importance, for the most degraded lagoons this should be accompanied by additional measures. As clear estimates of the real costs of active ecological restoration of lagoons are lacking so far, it is, however, still too early to make a cost-benefit analysis for conservation of the different restoration scenarios (De Groot et al., 2013).

In conclusion, the rationalized thinking about possible future ecosystem trajectories and consensus building within the focus group allowed us to engage a clear dialog with the socio-economic colleagues and develop the novel methodology (cf. Fig. 2) for coupling 
ecology with a socio-economic study of the perception of lagoon restoration projects study of the willingness to pay for them by residents and tourists. This study clearly addresses some of the key questions in the area of restoration ecology that both needs to cope with questions about technical feasibility based on sound ecological knowledge as well as with questions about human acceptability based on perceptions and costs. Hence, this transdisciplinary approach and novel methodology could therefore be applied more widely for the restoration ecology for of aquatic coastal ecosystems.

\section{ACKNOWLEDGEMENT}

This study was orally presented during the $6^{\text {th }}$ Eurolag conference that took place in Lecce (Italy) from 16-19 December 2012 in the session 5 "Conservation and management of coastal lagoons". The authors thank Hamédy Diop for realizing the majority of the interviews and all the experts (listed in Table S1) for their valuable contributions. Special thanks are due to Juliette Picot and Sebastien Pollet of the Syndicat Mixte des Etangs Littoraux (SIEL) and the Natura-2000 committee of the Palavasian lagoon complex, the municipality of Lattes and the Conservatoire du Littoral for their interest in this study. This study was financed by the Agence National de la Recherche through its Labex "Dispositif de Recherche Interdisciplinaire pour les Interactions Hommes-Milieux (DRIIHM)“, programme 'OHM Littoral méditterranéen'.

\section{REFERENCES}

Ahtiainen H, Artell J, Czajkowski M, Hasler B, Hasselström L, Hyytiäinen K, Meyerhoff J, Smart JCR, Söderqvist T, Khaleeva J et al. 2013. Public preferences regarding use and condition of the Baltic Sea - an international comparison informing marine policy. Marine Policy 42: 20-30. doi: 10.1016/j.marpol.2013.01.011

Anthony A, Atwood J, August P, Byron C, Cobb S, Foster C, Fry C, Gold A, Hagos K, Heffner L et al. 2009. Coastal lagoons and climate change: ecological and social ramifications in U.S. Atlantic and Gulf coast ecosystems. Ecology and Society 14: 8 [online] URL: http://www.ecologyandsociety.org/vol14/iss1/art8/

Aronson J, Claeys F, Westerberg V, Picon P, Bernard G, Bocognano J-M, De Groot R. 2012. Towards Sustainability and Tools for Restoring Natural Capital: Etang de Berre (Southern France) Case Study. In: Sustainability Science, Weinstein MP, Turner RE (eds). Springer: New York; 111-138. doi: 10.1007/978-1-4614-3188-6_6

Barbier EB, Hacker SD, Kennedy C, Koch EW, Stier AC, Silliman BR. 2011. The value of estuarine and coastal ecosystem services. Ecological Monographs 81: 169-193

Barnes RSK. 1980. Coastal lagoons; the natural history of a neglected habitat. Cambridge University Press, Cambridge, 106pp. 
Bec B, Collos Y, Souchu P, Vaquer A, Lautier J, Fiandrino A, Benau L, Orsoni V, Laugier T. 2011. Distribution of picophytoplankton and nanophytoplankton along an anthropogenic eutrophication gradient in French Mediterranean coastal lagoons. Aquatic Microbial Ecology 63: 29-45. doi:10.3354/ame01480

Borja A, Dauer DM, Elliott M, Simenstad CA. 2010. Medium- and long-term recovery of estuarine and coastal ecosystems: patterns, rates and restoration effectiveness. Estuaries and Coasts 33:1249-1260. doi: 10.1007/s12237-010-9347-5

Chomérat N, Garnier R, Bertrand C, A. Cazaubon A. 2007. Seasonal succession of cyanoprokaryotes in a hypereutrophic oligo-mesohaline lagoon from the South of France. Estuarine, Coastal and Shelf Science 72: 591-602 doi: 10.1016/j.ecss.2006.11.008

Council of the European Communities, 2000. Directive 2000/60/EC of the European Parliament and the Council of 23rd October 2000 establishing a framework for community action in the field of water policy. Official Journal of the European Communities L327: 1-72.

Cunha AH, Marbá NN,Van Katwijk MM, Pickerell C, Henriques M, Bernard G, Ferreira MA, Garcia S, Garmendia JM, Manent P. 2012. Changing Paradigms in Seagrass Restoration. Restoration Ecology 20 : 427-430 doi: 10.1111/j.1526100X.2012.00878.x

De Groot R, Brander L, Van der Ploeg S, Costanza R, Bernard F, Braat L, Christie M, Crossman $N$, Ghermandi A, Hein L et al. 2012. Global estimates of the value of ecosystems and their services in monetary units. Ecosystem Services 1: 50-61

De Groot R, Blignaut J, Van der Ploeg S, Aronson J, Farley J, Elmqvist T. 2013. Benefits of investing in ecosystem restoration. Conservation Biology 27: 1286-1293. doi: 111/cobi.12158

De Wit R, Stal LJ, Lomstein BA, Herbert RA, van Gemerden H, Viaroli P, Ceccherelli VU, Rodríguez-Valera F, Bartoli M, Giordani G et al. 2001. ROBUST: The ROle of BUffering capacities in STabilising coastal lagon ecosystems. Continental Shelf Research 21: 2021-2041.

De Wit R., Leibreich J, Vernier F, Delmas F, Beuffe H, Maison P, Chossat J-C, LaplaceTreyture C, Laplana R, Clavé V et al. 2005. Relationship between land-use in the agroforestry system of les Landes, nitrogen loading to and risk of macro-algal blooming in the Bassin d'Arcachon coastal lagoon (SW France). Estuarine Coastal Shelf Science 62: 453-465

Direction Régionale de l'Environnement, de l'Aménagement et du Logement (DREAL) de la Région Languedoc-Roussillon, 2010. Modernisation de l'inventaire ZNIEFF : ZNIEFF de type I ${ }^{\circ}$ 0000-3013 Etang du Méjean-Pérols. 7p. http://irlr-app.dreal-languedocroussillon.fr/ addsd/ZNIEFF/pdf/znieff_0000-3014.pdf [14 October 2014]

Duarte CM. 199l. Seagrass depth limits. Aquatic Botany 40: 363-377 
Duarte CM, Conley DJ, Carstensen J, Sánchez-Camacho M. 2009. Return to neverland: shifting baselines affect eutrophication restoration targets. Estuaries and Coasts 32: 29-36. doi: 10.1007/s12237-008-9111-2

Elliott M, Burdon D, Hemingway KL, Apitz SE. 2007. Estuarine, coastal and marine ecosystem restoration: Confusing management and science: A revision of concepts. Estuarine, Coastal and Shelf Science 74: 349-366.

Eppesen R, Søndergaard M, Jensen JP, Havens KE, Anneville O, Carvalho L, Coveney MF, Deneke R, Dokulil M, Foy B et al.. 2005. Lake responses to reduced nutrient loadingan analysis of contemporary long-term data from 35 case studies. Freshwater Biology 50: 1747-1771. doi:10.1111/j.1365-2427.2005.01415.x.

Guyoneaud R, De Wit R, Matheron R, Caumette P. 1998. Impact of macroalgal dredging on dystrophic crises and phototrophic bacterial blooms (red waters) in a brackish coastal lagoon (Prévost lagoon, France), Oceanologica Acta 21: 551-561

Hanley N, Mourato S, Wright R.E.. 2001. Choice Modelling Approaches: A superior alternative for Environmental Valuation? Journal of Economics Surveys 15: 435-462

Hebert M, Dupré N, Barral M, Messiaen G, Oheix J, Deslous-Paoli J-M, Roque d'Orbcastel $\mathrm{E}$, Laugier T. 2012. Programme de réimplantation d'herbiers de phanérogames (Zostera noltiil Ruppia cirrhosa) dans les lagunes de Bages, Ingril et Thau (Languedoc-Roussillon - France), Rapport Cépralmar: 07-2012. Report in French: http://archimer.ifremer.fr/doc/00089/20062/17703.pdf

Ifremer. 2002. Réseau de Suivi Lagunaire du Languedoc-Roussillon : Bilan des résultats 2001. Chapitre 11 Etangs Palavasiens http://rsl.cepralmar.com/doc/RSL-01-11.pdf

Ifremer. 2005. Réseau de Suivi Lagunaire du Languedoc-Roussillon : Bilan des résultats 2004. Chapitre 11 Etangs Palavasiens. http://rsl.cepralmar.com/doc/RSL-04-11.pdf

Ifremer. 2007. Réseau de Suivi Lagunaire du Languedoc-Roussillon : Bilan des résultats 2006. http://archimer.ifremer.fr/doc/00118/22926/

Ifremer. 2010. Réseau de Suivi Lagunaire du Languedoc-Roussillon : Bilan des résultats 2009. http://archimer.ifremer.fr/doc/00118/22919/

Ifremer. 2013. Réseau de Suivi Lagunaire du Languedoc-Roussillon. Bilan des résultats 2012. http://archimer.ifremer.fr/doc/00148/25940/

Ifremer. 2014. Réseau de Suivi Lagunaire du Languedoc-Roussillon. Bilan des résultats 2013. http://archimer.ifremer.fr/doc/00210/32154/

Jaeck M, Lifran R. 2013. Farmers' preferences for production practices: a choice experiment study in the Rhone river delta. Journal of Agricultural Economics 65: 112-130 doi: 10.1111/1477-9552.12018

Kuhfuss L, Rey-Valette H, Sourisseau E. 2010. Typologie des systèmes lagunaires en Languedoc-Roussillon en fonction des types de services rendus. Revue de l'économie méridionale (REM), 58 ( $\left.{ }^{\circ} 229-230\right)$ : 9-24. 
Lenzi M, Palmieri R, Porrello S. 2003. Restoration of the eutrophic Orbetello lagoon (Tyrrhenian Sea, Italy): water quality management. Marine Pollution Bulletin 46: 1540-1548

Meinesz C, Derolez V, Bouchoucha M. 2013. Base de données "pressions sur les lagunes méditérranéennes" - Analyse des liens état - pression. Report in French. Agence de l'Eau Rhône-Méditeranée-Corse, Montpellier, France

Millennium Ecosystem Assessment. 2005. Ecosystems and Human Well-being: Synthesis. Island Press, Washington, DC.

http://www.millenniumassessment.org/documents/document.356.aspx.pdf

Nixon SW. 1995. Coastal marine eutrophication-a definition, social causes, and future concerns. Ophelia 41: 199-219.

Norgaard RB. 2010. Ecosystem services: from eye-opening metaphor to complexity blinder. Ecological Economics 69: 1219-1227. doi:10.1016/j.ecolecon.2009.11.009

Nunes PALD, Rossetto L, De Blaeij A. 2004. Measuring the economic value of alternative clam fishing management practices in the Venice Lagoon: results from a conjoint valuation application. Journal of Marine Systems 51: 309-320

Orfanidis S, Panayotidis P, Stamatis N. 2003. An insight to the ecological evaluation index (EEI). Ecological Indicators 3: 27-33.

Orth RJ, McGlathery KJ, Heck KL Jr (eds). 2012. Theme section: Eelgrass recovery induces state changes in a coastal bay system. Marine Ecology Progress Series 434:171-301 http://www.int-res.com/articles/theme/m448_ThemeSection.pdf

Ouisse V, Fiandrino A, De Wit R, Malet N. 2013. Restauration des écosystèmes lagunaires : évaluation du rôle du sédiment et des herbiers à phanérogames Rapport final du Contrat n 2012 1835. Report in French, Agence de l'Eau Rhône-Méditeranée-Corse, Montpellier, France: http://archimer.ifremer.fr/doc/00166/27774/

Pilkaitytė R, Razinkovas A. 2006. Factors controlling phytoplankton blooms in a temperate estuary: nutrient limitation and physical forcing. Hydrobiologia 555: 41-48

Razinkovas A., Gasiünaité, Viaroli P, \& Zaldívar J-M. 2008. European lagoons - need for further comparison across spatial and temporal scales. Hydrobiologia 611: 1-179.

"Réseau de Suivi Lagunaire" (RSL). 2014. http://rsl.cepralmar.com/sites/c09/2005.html (in French, a menu option allows to check for different years and the site provides the possibility to download more detailed reports in French) [14 October 2014]

Schramm W. 1999. Factors influencing seaweed responses to eutrophication: some results from EU-project EUMAC. Journal of Applied Phycology 11: 69-78.

Society for Ecological Restoration International Science \& Policy Working Group. 2004. The SER International Primer on Ecological Restoration. www.ser.org \& Tucson : Society for Ecological Restoration International: http://www.ser.org/resources/resources-detail-view/ser-international-primer-onecological-restoration\#3 [28 July 2015] 
Souchu P, Bec B, Smith VH. Laugier T, Fiandrino A, Benau L, Orsoni V, Collos Y, Vaquer A. 2010. Patterns in nutrient limitation and chlorophyll a along an anthropogenic eutrophication gradient in French Mediterranean coastal lagoons. Canadian Journal of Fisheries and Aquatic Sciences 67: 743-753. doi:10.1139/F10-018

Syndicat mixte des étangs littoraux (SIEL) and P2A Développement SARL. 2012. Réalisation d'un état de référence des herbiers à phanérogames sur les étangs d'Ingril Sud et des Mouettes. rapport in French, 68 pages, Villeneuve-lès-Maguelone, France.

Syndicat mixte des étangs littoraux (SIEL). 2009a. DOCOB Natura 2000 des sites « Etangs palavasiens et étang de l'Estagnol » Tome II, Atlas Cartographique. 36p. Villeneuve-lèsMaguelone, France.

Syndicat mixte des étangs littoraux (SIEL). 2009b. DOCOB Natura 2000 des sites « Etangs palavasiens et étang de l'Estagnol » Tome III : concertation et fiches habitats naturels et espèces d'intérêt communautaire. 159 p. Villeneuve-lès-Maguelone, France.

Syndicat mixte des étangs littoraux (SIEL), 2010. DOCOB Natura 2000 des sites « Etangs palavasiens et étang de l'Estagnol » Tome I, Rapport du DOCOB. 364 p. Villeneuve-lèsMaguelone, France.

Valiela I, McLelland J, Hauxwell J, Behr PJ, Hersh D, Foreman K. 1997. Macroalgal blooms in shallow estuaries: controls and ecophysiological and ecosystem consequences. Limnology and Oceanography 42: 1105-1118.

Van Katwijk MM, Bos AR, De Jonge VN , Hanssen LSA, Hermus DCR, De Jong DJ. 2009. Guidelines for seagrass restoration: importance of habitat selection and donor population, spreading of risks, and ecosystem engineering effects. Marine Pollution Bulletin 58:179-188.

Viaroli P, Bartoli M, Giordano G, Naldi M, Orfanidis S, Zaldivar JM. 2008. Community shifts, alternative stable states, biogeochemical controlsand feedbacks in eutrophic coastal lagoons: a brief overview. Aquatic Conservation: Marine Freshwater Ecosystems 18: 105-117. doi: 10.1002/aqc.956

Villéger, S, Ferraton, F, Mouillot, D, De Wit R. 2012. Nutrient recycling by coastal macroorganisms: intra vs. interspecific differences. Marine Ecology Progress Series 452: 297303. doi: $10.3354 /$ meps 09610

Westerberg VH, Lifran R, Olsen SB. 2010. To restore or not? A valuation of social and ecological functions of the Marais des Baux wetland in Southern France. Ecological Economics 69: 2383-2393.

Zaldívar J-M, Cardoso AC, Viaroli P, Newton A, De Wit R, Ibañez C, Reizopoulou S, Somma F, Razinkovas A, Basset A et al. 2008. Eutrophication in transitional waters: an overview. Transitional Waters Monographs 2: 1-78. 
Tables

Table 1: Demographic and sociological profiles of the respondents and of the Urban Area of Montpellier (Agglomération de Montpellier). Sixty-

eight of the resident respondents (72\%) lived in the municipality of Montpellier. In between brackets is year of the census.

\begin{tabular}{|c|c|c|c|c|c|c|c|c|c|c|c|c|}
\hline & \multirow[t]{2}{*}{$\mathbf{N}$} & \multirow{2}{*}{$\begin{array}{c}\text { Gender } \\
\text { male/ } \\
\text { female }\end{array}$} & \multicolumn{4}{|c|}{ Age - class (years) } & \multirow{2}{*}{\begin{tabular}{|c|}
$\begin{array}{c}\text { Region of } \\
\text { birth }\end{array}$ \\
$\begin{array}{c}\text { Languedoc- } \\
\text { Roussillon }\end{array}$ \\
\end{tabular}} & \multicolumn{2}{|c|}{ Marital status } & \multicolumn{3}{|c|}{ Children } \\
\hline & & & $18-30$ & $31-45$ & $45-65$ & $>65$ & & $\begin{array}{c}\text { single, } \\
\text { widow, } \\
\text { divorced }\end{array}$ & $\begin{array}{c}\text { married or } \\
\text { living in } \\
\text { couple }\end{array}$ & None & 1 or 2 & $>2$ \\
\hline \multirow[t]{2}{*}{ Residents } & 94 & $49 / 45$ & 38 & 15 & 26 & 15 & 35 & 54 & 40 & 49 & 30 & 15 \\
\hline & & $\begin{array}{l}52.1 \% / \\
47.8 \%\end{array}$ & $40.4 \%$ & $16.0 \%$ & $27.7 \%$ & $16.0 \%$ & $37.2 \%$ & $57.4 \%$ & $42.6 \%$ & $52.1 \%$ & $31.9 \%$ & $16.0 \%$ \\
\hline \multirow[t]{2}{*}{ Tourists } & 65 & $35 / 30$ & 23 & 17 & 18 & 7 & 11 & 37 & 28 & 50 & 12 & 3 \\
\hline & & $\begin{array}{c}53.8 \% / \\
46.2 \%\end{array}$ & $35.4 \%$ & $26.2 \%$ & $27.7 \%$ & $10.8 \%$ & $16.9 \%$ & $56.9 \%$ & $43.1 \%$ & $76.9 \%$ & $18.5 \%$ & $4.6 \%$ \\
\hline $\begin{array}{l}\text { Urban Area of } \\
\text { Montpellier }\end{array}$ & $\begin{array}{c}406139 \\
(2006)\end{array}$ & & $43.6 \%$ & \multicolumn{2}{|c|}{$43.7 \%$} & $13.8 \%$ & Not informed & $54.0 \%$ & $46.0 \%$ & $67.6 \%$ & 28.6 & $3.8 \%$ \\
\hline
\end{tabular}


Table 2: Uses of the lagoons by the interviewees. Percentages standardized to number of respondents $(n=94$, and $n=65$ for residents and tourists, respectively. Note total sums above $100 \%$ as certain respondents indicated multiple uses).

\begin{tabular}{|l|cc|cc|}
\cline { 2 - 5 } \multicolumn{1}{c|}{} & \multicolumn{2}{c|}{ residents } & \multicolumn{2}{c|}{ tourists } \\
\hline Do not visit lagoons and do not use them & $\mathbf{3 8}$ & $40.4 \%$ & $\mathbf{4 5}$ & $69.2 \%$ \\
\hline & & & & \\
\hline Walking, bird watching enjoying nature & $\mathbf{4 4}$ & $46.8 \%$ & $\mathbf{1 5}$ & $23.1 \%$ \\
\hline Cycling & $\mathbf{2 9}$ & $30.9 \%$ & $\mathbf{1 0}$ & $15.4 \%$ \\
\hline Nautical sports (kayak, kite surf, etc.) & $\mathbf{7}$ & $7.4 \%$ & $\mathbf{1}$ & $1.5 \%$ \\
\hline Walking with a dog & $\mathbf{4}$ & $4.3 \%$ & $\mathbf{0}$ & $0.0 \%$ \\
\hline Horse and poney trekking & $\mathbf{3}$ & $3.2 \%$ & $\mathbf{1}$ & $1.5 \%$ \\
\hline Fishing & $\mathbf{1}$ & $1.1 \%$ & $\mathbf{0}$ & $0.0 \%$ \\
\hline & & & & $110.8 \%$ \\
\hline Total*) & \multicolumn{2}{|c|}{$134.0 \%$} & & \\
\hline
\end{tabular}


Table 3: Reasons invoked for not visiting the lagoons, percentages have been standardized to the subsamples of non-users of lagoons, i.e. $\mathrm{n}=38$ and $\mathrm{n}=45$ for residents and tourists, respectively (Note total sum of reasons invoked exceed $100 \%$ as some respondents invoked multiple reasons).

\begin{tabular}{|l|cc|cc|}
\cline { 2 - 5 } \multicolumn{1}{c|}{} & \multicolumn{2}{c|}{ residents } & \multicolumn{2}{c|}{ tourists } \\
\hline I don't know the lagoons & $\mathbf{1 0}$ & $26 \%$ & $\mathbf{2 6}$ & $58 \%$ \\
\hline The lagoons are too far away & $\mathbf{9}$ & $24 \%$ & $\mathbf{6}$ & $13 \%$ \\
\hline I am not interested in the lagoons & $\mathbf{8}$ & $21 \%$ & $\mathbf{4}$ & $9 \%$ \\
\hline The lagoons are polluted and smell badly & $\mathbf{6}$ & $16 \%$ & $\mathbf{2}$ & $4 \%$ \\
\hline Other reasons & $\mathbf{4}$ & $11 \%$ & $\mathbf{8}$ & $18 \%$ \\
\hline No response & $\mathbf{4}$ & $11 \%$ & $\mathbf{2}$ & $4 \%$ \\
\hline & & & & $107 \%$ \\
\hline Total*) & & $108 \%$ & & \\
\hline
\end{tabular}


Table 4: Identification of top priorities by the respondents among the selected ecosystem services proposed in the survey. These proposed ecosystem services have been grouped according 3 of the 4 major types of services used in the Milenium Ecosystem Assesment (2005). Note that the type of provisioning services has not been proposed to the interviewees and that for the top two priorities the total percentages sum up to $200 \%$ of respondents as each respondent replied two priorities.

\begin{tabular}{|c|c|c|c|c|c|c|c|c|}
\hline & \multicolumn{4}{|c|}{ Top 1 priority } & \multicolumn{4}{|c|}{ Cited among the first top two priorities } \\
\hline & \multicolumn{2}{|c|}{ residents } & \multicolumn{2}{|c|}{ tourists } & \multicolumn{2}{|c|}{ residents } & \multicolumn{2}{|c|}{ tourists } \\
\hline Supporting services & 49 & $52.1 \%$ & 39 & $60.0 \%$ & 78 & $83.0 \%$ & 56 & $86.2 \%$ \\
\hline Biodiversity & 49 & $52.1 \%$ & 39 & $60.0 \%$ & 78 & $83.0 \%$ & 56 & $86.2 \%$ \\
\hline Regulating services & 36 & $38.3 \%$ & 19 & $29.2 \%$ & 61 & $64.9 \%$ & 43 & $66.2 \%$ \\
\hline Flood regulation & 15 & $16.0 \%$ & 7 & $10.8 \%$ & 23 & $24.5 \%$ & 13 & $20.0 \%$ \\
\hline Water purification & 21 & $22.3 \%$ & 12 & $18.5 \%$ & 38 & $40.4 \%$ & 30 & $46.2 \%$ \\
\hline
\end{tabular}




\begin{tabular}{|c|c|c|c|c|c|c|c|c|}
\hline Cultural services & 9 & $9.6 \%$ & 7 & $10.8 \%$ & 49 & $52.1 \%$ & 31 & $47.7 \%$ \\
\hline Enjoying landscape & 5 & $5.3 \%$ & 5 & $7.7 \%$ & 18 & $19.1 \%$ & 17 & $26.2 \%$ \\
\hline Recreational fishing & 1 & $1.1 \%$ & 0 & $0.0 \%$ & 4 & $4.3 \%$ & 1 & $1.5 \%$ \\
\hline Hunting & 0 & $0.0 \%$ & 0 & $0.0 \%$ & 1 & $1.1 \%$ & 0 & $0.0 \%$ \\
\hline Walking, leasure & 3 & $3.2 \%$ & 2 & $3.1 \%$ & 26 & $27.7 \%$ & 13 & $20.0 \%$ \\
\hline sum $=$ & & $100 \%$ & & $100 \%$ & & $200 \%$ & & $200 \%$ \\
\hline
\end{tabular}


Table 5: Different opinions adopted by the respondents corresponding to their willingness to financially contribute to the active restoration of the Méjean lagoon. ( $n=94$, and $n=65$ for residents and tourists, respectively. Note total sums above $100 \%$ as certain respondents indicated multiple reasons that motivated their reluctance to pay).

\begin{tabular}{|l|cc|cc|}
\hline & \multicolumn{2}{|c|}{ residents } & \multicolumn{2}{c|}{ tourists } \\
\hline $\begin{array}{l}\text { I am not opposed to contribute } \\
\text { financially }\end{array}$ & 66 & $70.2 \%$ & 43 & $66.2 \%$ \\
\hline I don't want to pay a new tax & 16 & $17.0 \%$ & 17 & $26.2 \%$ \\
\hline $\begin{array}{l}\text { I don't believe that my contribution } \\
\text { will be effectively used for the } \\
\text { restoration of the Etang de Méjean }\end{array}$ & 15 & $16.0 \%$ & 4 & $6.2 \%$ \\
\hline $\begin{array}{l}\text { It is not up to me to finance the } \\
\text { restoration project }\end{array}$ & 10 & $10.6 \%$ & 3 & $4.6 \%$ \\
\hline & 107 & $113.8 \%$ & 67 & $103.1 \%$ \\
\hline Total: & \multicolumn{2}{|c|}{$10.2 \%$} \\
\hline
\end{tabular}




\section{Legends to Figures}

Fig. 1. A map of the seven lagoons of the Palavas lagoon complex indicating the contour of the Natura 2000 protected area (broken line) and of the geographic location of the WWTP of the Montpellier agglomeration (450 000 inhabitants) and its outfall $11 \mathrm{~km}$ offshore in the Mediterranean Sea.

Fig. 2. Flow diagram of the procedures followed for the integrated ecological socio-economic study, showing the different tasks for the focus group and for the socio-economic part of the study.

Fig. 3. The sedimentary contents (top $5 \mathrm{~cm}$ ) of total $\mathrm{N}$ and $\mathrm{P}$ in the sediments of the seven lagoons from the Palavas complex (sampled in 1999. 2001, 2006, and 2012).

Fig. 4. Predicted ecosystem trajectories for Ingril (green line) and Méjean (red line) lagoons according the focus group and additional experts based on the 3 hypothesis and the monitoring observations between 2006 and 2012. The broken red line indicates the predicted impact of the additional measures proposed for the project of active restoration of the Méjean lagoon.

Fig. 5. Frequency of WTP by residents for the 4 different scenarios. Values expressed per year.

Fig. 6. Frequency of WTP by tourists for the 4 different scenarios. Values expressed per week. 
Figure 1

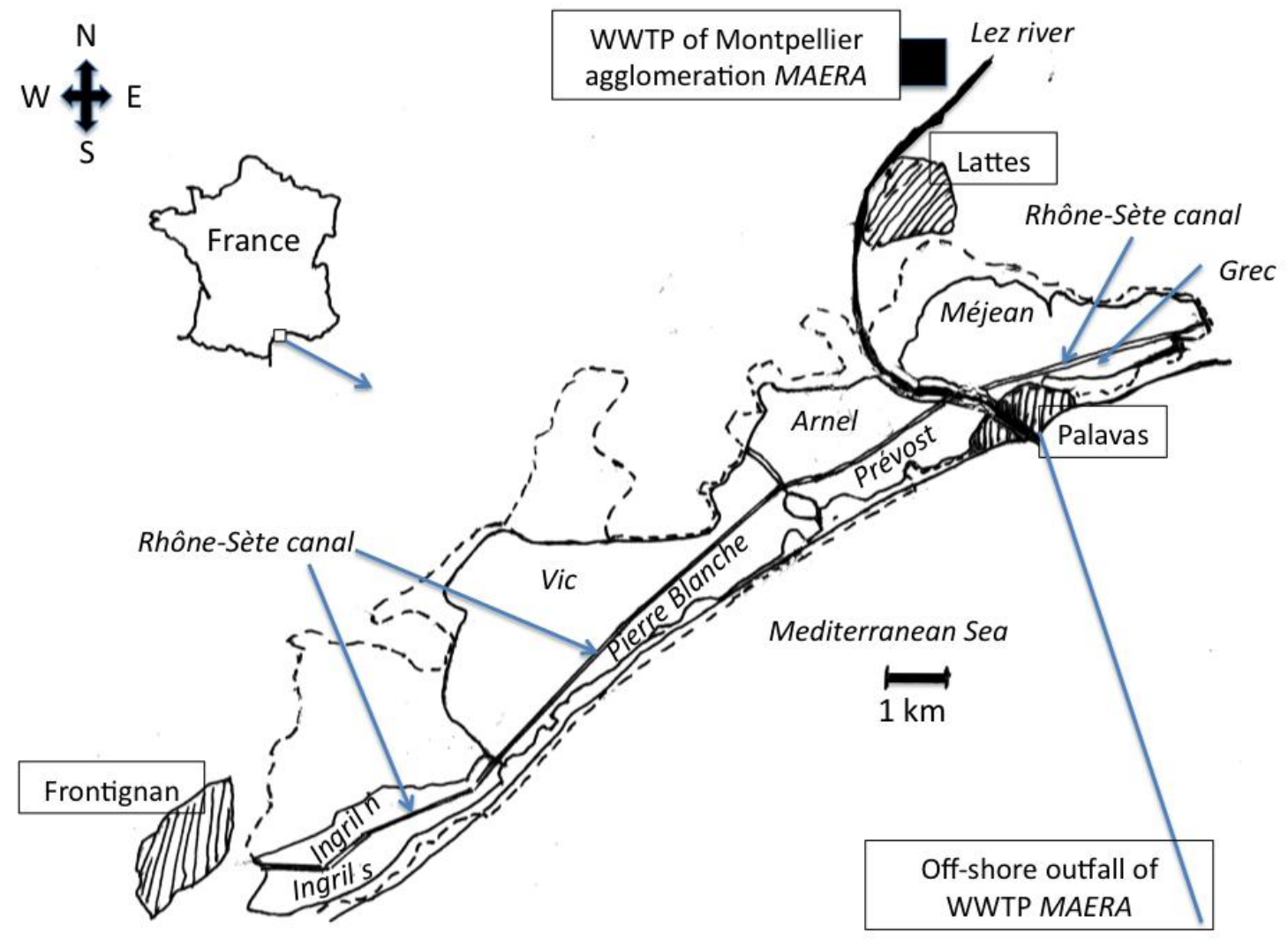


Figure 2

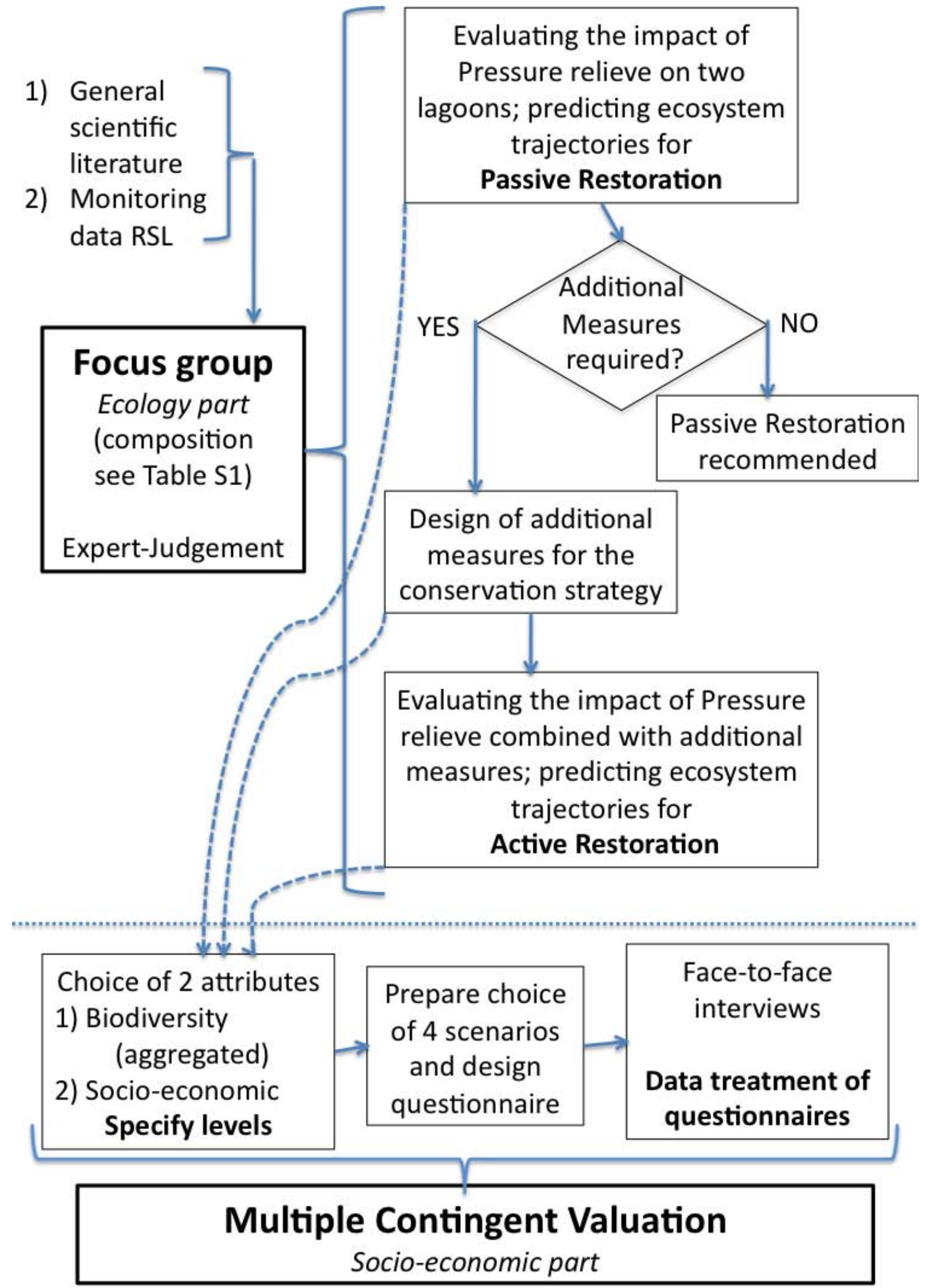


Figure 3

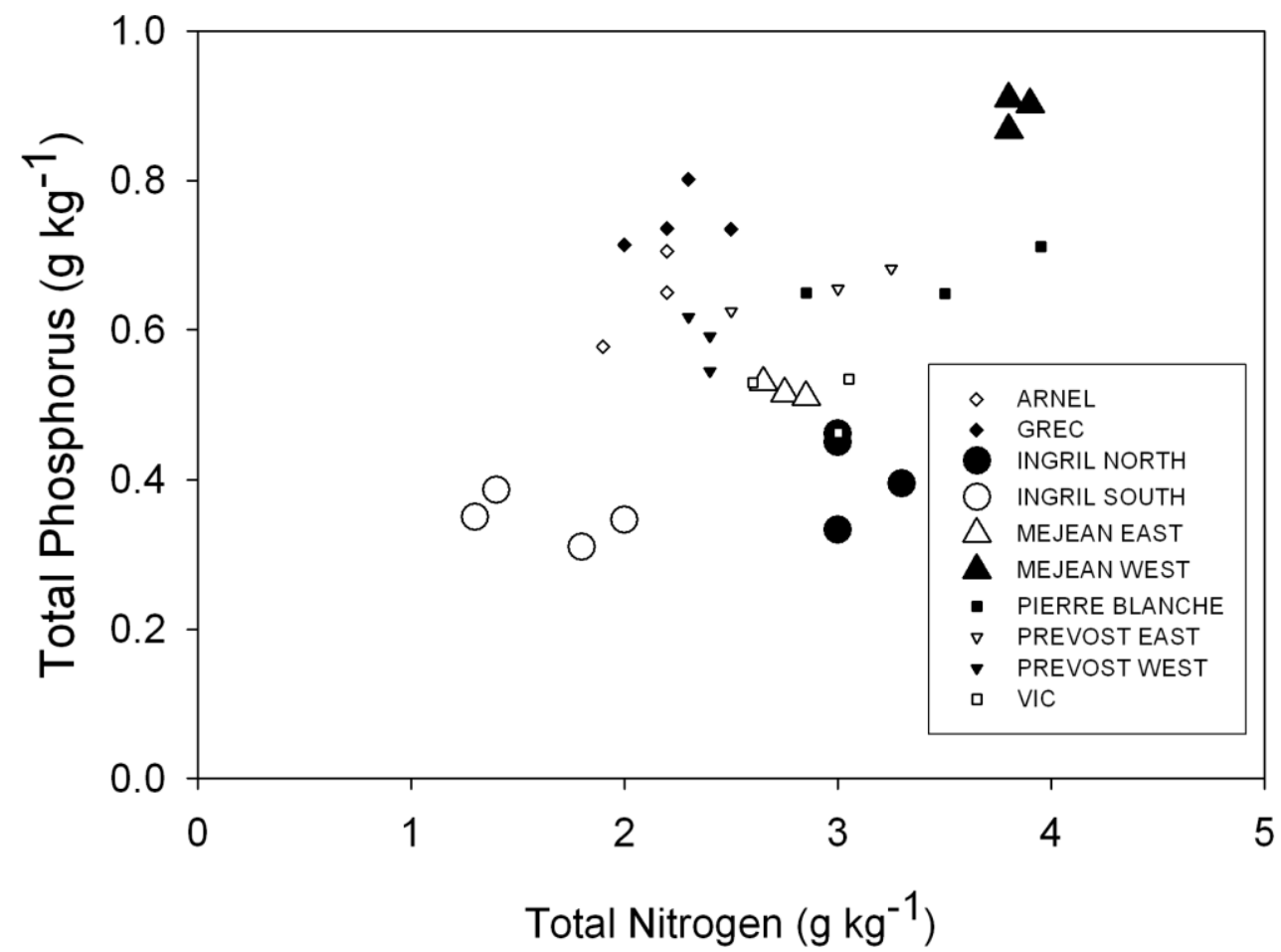

Figure 4
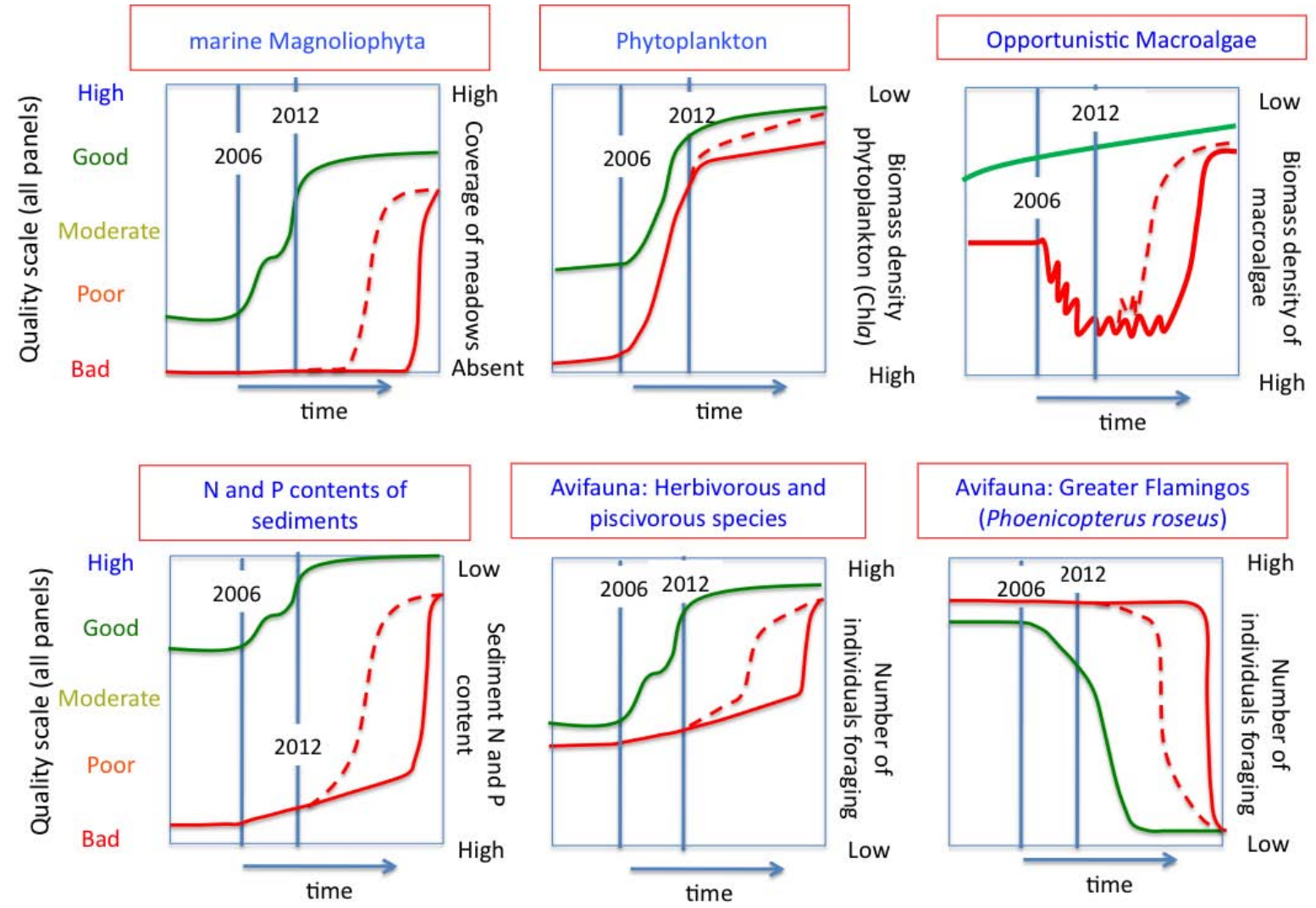

Avifauna: Herbivorous and piscivorous species

Avifauna: Greater Flamingos (Phoenicopterus roseus)
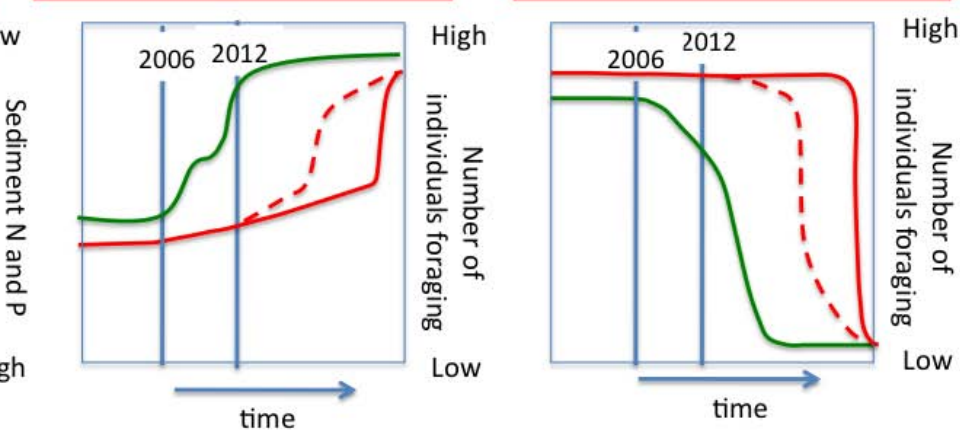
Figure 5

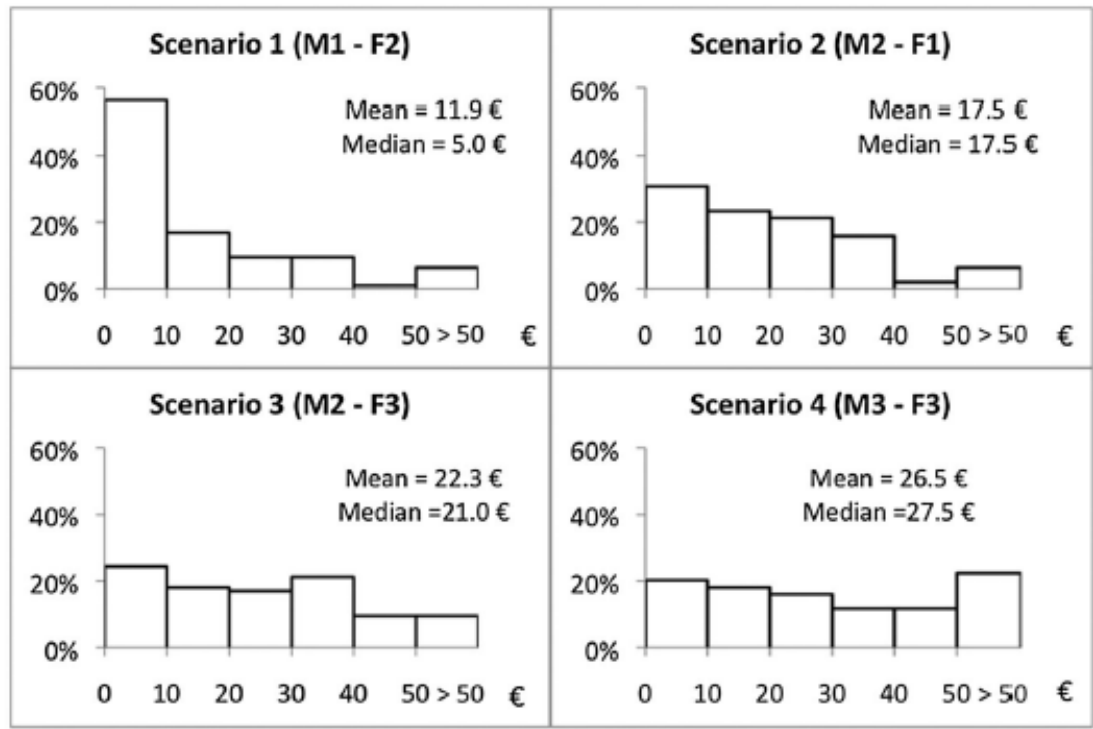

Figure 6

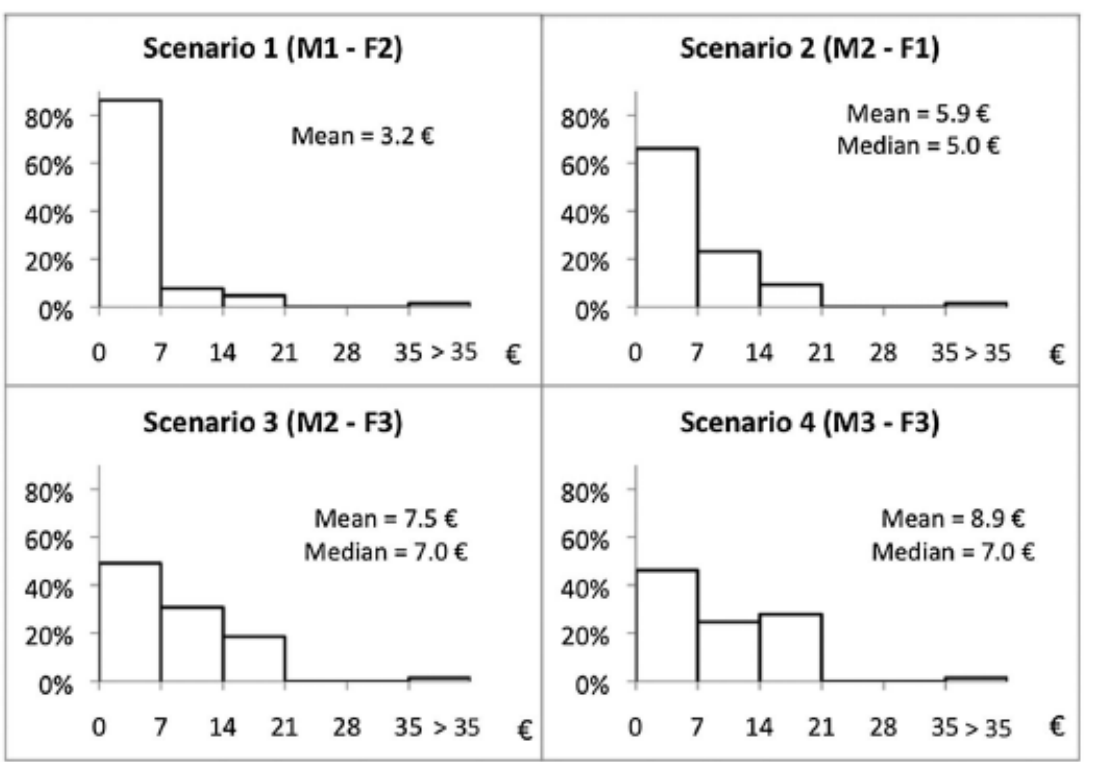




\section{Supporting Information}

\section{Appendices}

Appendix S1: Questionnaire and supporting graphic material used in this study for faceto-face interviews with residents of the Montpellier urban area and its surroundings.

Appendix S2: Questionnaire and supporting graphic material used in this study for faceto-face interviews with tourists visiting the beaches, lagoons and waterways of the Palavas lagoon complex.

Tables:

Table S1: Names and disciplines of the authors and specialization of the experts of the focus group and those consulted separately.

Table S2: Socio-economic categories of the respondents and comparison with the proportion for the whole population of the Montpellier Urban Area

Table S3: Income classes of respondents, declared by the respondents in the Survey.

Table S4: Results of the economometric calculations (statistics) to infer WTP for the biodiversity and access attributes, respectively. 


\section{Enquête sur les préférences pour la restauration des étangs palavasiens}

Version Habitants de Montpellier et de sa région.

Depuis les années 1960, les étangs palavasiens ont été dégradés par des apports excessifs d'azote et de phosphore. Ces apports principalement issus de la station d'épuration de Montpellier ont entrainé une dégradation du milieu et de la qualité de l'eau. C'est l'étang du Méjean qui est le plus touché. L'agglomération de Montpellier en collaboration avec La Région et l'Agence de l'Eau ont financé la construction fin 2005 d'un émissaire en mer qui réduit considérablement l'impact de la station d'épuration sur les étangs. La qualité de l'eau s'est donc fortement améliorée. Cependant de grandes quantités d'azote et de phosphore ont été stockées dans les sédiments et sont régulièrement larguées dans l'eau L'atteinte d'un bon état écologique, comme le réclame la directive européenne sur l'eau va donc prendre beaucoup de temps (plus de 50 ans). Selon les experts, il est possible de raccourcir ce délai de façon importante par la restauration des herbiers dans l'étang. Plusieurs options sont possibles. Cette enquête vise à identifier vos préférences par rapport à ces options qui auront des coûts et des bénéfices différents pour la société.

Cette enquête est réalisée par le CNRS et l'Université de Montpellier. Elle vise à recueillir les préférences des habitants et des touristes sur les modalités d'amélioration de la qualité des eaux des étangs palavasiens.

Les données individuelles ou opinions recueillies dans cette enquête sont strictement confidentielles et seront uniquement utilisées dans un but de recherche. Elles feront l'objet d'un traitement statistique.

En aucun cas, elles ne pourront être utilisées par les administrations ou les collectivités territoriales.

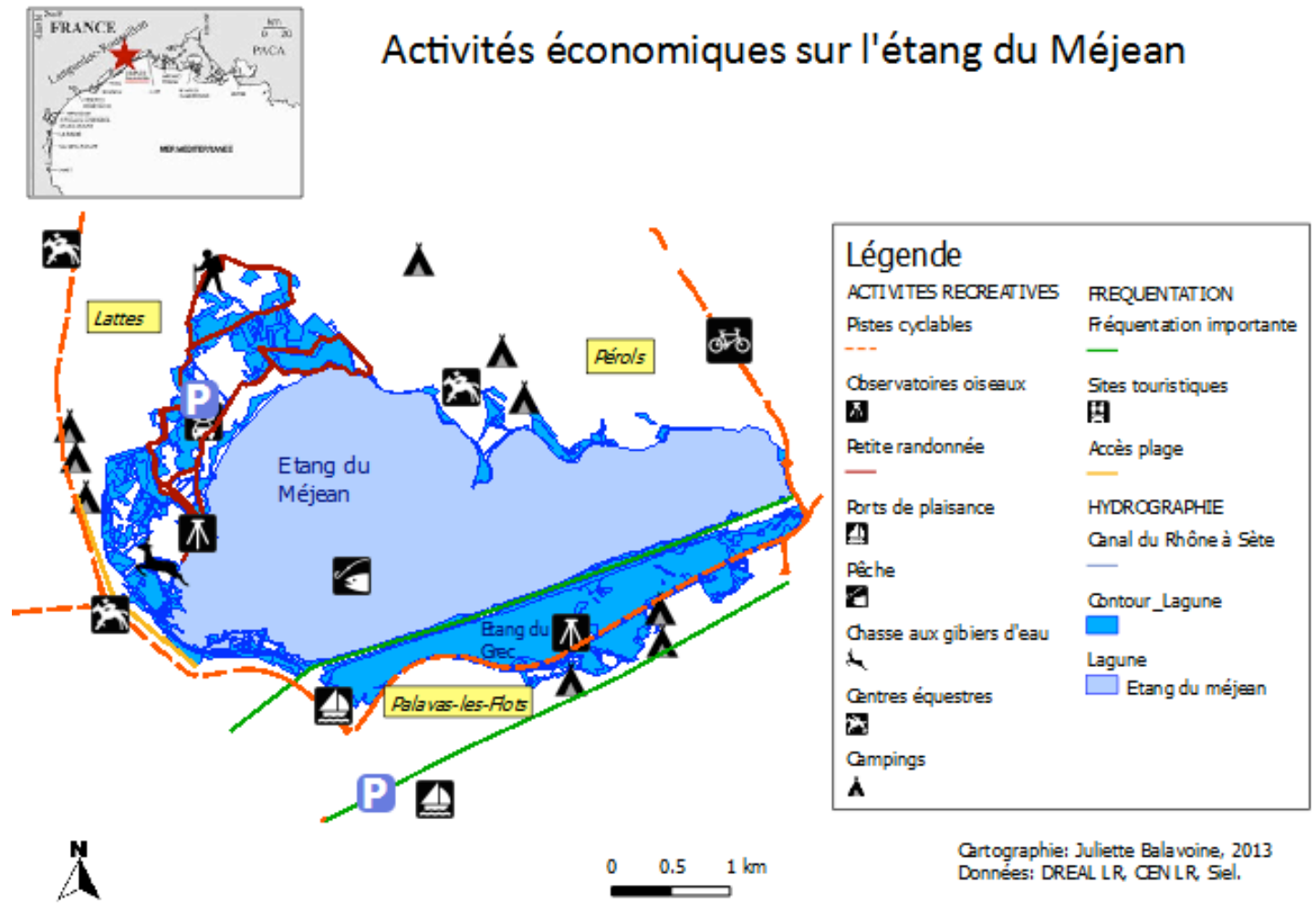


A1- Dans quelle commune habitez-vous ?

A2- Depuis combien de temps vous y habitez ?

A3- Etes vous originaire de la région Languedoc Roussillon? Oui Non

A4- Connaissiez-vous l'existence des étangs palavasiens avant cette enquête ?

Oui j'y suis déjà allé Oui j'en ai entendu parler Non (->question A-9)

A5- Quelle est la fréquence de votre fréquentation des étangs palavasiens ? (préciser qu'il ne s'agit pas seulement de passer devant mais de s'arrêter et au moins descendre de voiture)

\begin{tabular}{|l|l|l|l|l|l|l|l|}
\hline & Moins 1 fois/ an & & 1 fois /an & & 1 à 2 fois/an & & Plus de 2 fois/ an \\
\hline
\end{tabular}

A6-Dans quelle zone du Méjean allez-vous en priorité ? (voir la carte) $\square$ Piste cyclable $\square$ chemin de halage $\square$ sentier de la maison de la nature

A7-Combien de fois avez-vous visité la maison de la nature de Lattes ?

\begin{tabular}{|l|l|l|l|l|l|l|}
\hline & Jamais & 1 fois /an & 1 à 2 fois/an & & Plus de 2 fois/ an \\
\hline
\end{tabular}

A8-Si vous fréquentez les zones des étangs quelles sont les activités que vous pratiquez ?

\begin{tabular}{|l|l|l|l|}
\hline & Promenade à pied, découverte de la nature & Sports nautiques \\
\hline & Promenade à vélo & & Pêche de loisir \\
\hline Promenade à cheval & & Chasse \\
\hline Promenade du chien & & Autre : précisez \\
\hline
\end{tabular}

A9- Si non, pourquoi ne fréquentez-vous pas les zones des étangs?

\begin{tabular}{|l|l|}
\hline & Ça ne m'intéresse pas \\
\hline & Ils sont trop loin \\
\hline & Ils ne sont pas accessibles \\
\hline & Je ne connais pas ces étangs \\
\hline & Ils sont trop pollués / odeurs gênantes \\
\hline & Autres précisez \\
\hline
\end{tabular}

A10- Vous arrive-t-il de vous rendre près d'autres étangs

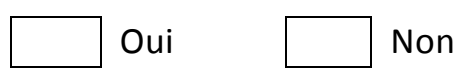

\section{B) PRESENTATION DU PROJET DE RESTAURATION}

Le projet de restauration qui est envisagé repose sur la reconstitution des herbiers au fond de l'étang car ces herbiers favorisent à une amélioration de la qualité de l'eau et le développement de la biodiversité. Un étang avec des vastes herbiers présente un habitat pour les canards, les cygnes sauvages et les hippocampes qui sont des espèces emblématiques des lagunes de la région. Ces améliorations du milieu bénéficieront aussi directement à la population car il y aura moins de mauvaises odeurs à proximité des étangs, il sera plus agréable de s'y promener et on pourra observer plus d'oiseaux. 
- Dans une première phase (pendant 4 à 5 ans) il faut favoriser le développement de macro-algues qui seront récoltées et emportées, ce qui diminuera la pollution accumulée dans le sédiment. Cela permet de créer des conditions propices au développement ultérieur de l'herbier.

- Dans une seconde phase, il s'agit d'implanter des herbiers pour favoriser une couverture optimale de la surface.

Plusieurs options sont possibles pour réaliser cette restauration. Ce sont ces options que nous allons vous présenter et vous demander d'évaluer.

Premièrement on peut fixer plusieurs objectifs de reconstitutions des herbiers. Plus il y a d'herbiers et plus la qualité de l'eau et de la biodiversité sera grande. Par contre la présence d'herbiers ne permet pas aux flamands roses d'avoir un accès facile à leurs proies dans le sédiment. Donc plus il y a $d^{\prime}$ 'herbiers et plus on peut s'attendre à une diversité d'espèces, notamment des cygnes, des canards et des hippocampes, mais à moins de flamants roses.

Trois niveaux de couverture sont envisagés:

- FAIBLE (beaucoup de flamants, environnement non favorable à la présence de cygnes, hippocampes, qualité de l'eau améliorée mais ne remplit pas les critères de bonne état de la Directive Cadre sur l'Eau (DCE)

- MOYEN (moins de flamants, environnement peu favorable à la présence de d'hippocampes, de cygne ou de canards, qualité de l'eau améliorée, mais risque $d^{\prime}$ être considérée pas encore assez bonne selon les critères de la DCE)

- ELEVE (peu de flamants, environnement favorable à l'installation d' hippocampes, de cygnes et de canards, bonne qualité de l'eau correspondant aux critères de la DCE)

Le développement de cette biodiversité et notamment des espèces d'oiseaux va rendre les étangs plus attractifs pour les promeneurs. On peut donc envisager par exemple d'aménager des sentiers de promenades, des postes d'observation des oiseaux. Cependant il ne faut pas que les promeneurs fassent fuir les oiseaux. Il faut pouvoir gérer le dérangement occasionné par ces promeneurs (bruit, piétinent des nids...).

Trois choix d'aménagement ont donc aussi été retenus.

- Conservation des sentiers actuels comme moyen d'accès de la zone.

- Multiplier le nombre de sentiers pour favoriser l'accessibilité du site et les promenades mais avec un effet de dérangement pour les oiseaux

- Augmenter les sentiers mais avec des aménagements qui permettent de limiter le dérangement des oiseaux

Enfin bien sûr, ces différentes options vont avoir un impact sur le coût du projet.

II s'agit ici de savoir combien vous seriez prêt à payer pour plusieurs scénarios possibles qui combinent les différentes options de couverture des herbiers et d'aménagement. La réalisation du projet pourrait être en partie financé par des fonds publics (européens et régionaux) car ce sera un des projets les plus importants de restauration des herbiers en France, mais il aurait aussi des répercussions sur votre facture d'eau qui comprend une partie de taxe de lutte contre la pollution 
(autrefois appelée taxe d'assainissement) collectée par l'Agence de l'eau ou sur la taxe de séjour des touristes.

Pour vous permettre de situer les ordres de grandeur, la taxe est actuellement de 0,28 euros par M3 et la consommation nationale de référence pour un ménage de 2 personnes est de $130 \mathrm{~m} 3 / \mathrm{an}$. Le montant de la taxe correspondante est donc de 38 euros par an.

A titre indicatif, vous pouvez vous référer à votre dernière facture d'eau (consommation semestrielle) si vous l'avez en mémoire.

Nous allons maintenant vous présenter 4 scénarios qui permettent de combiner les différentes options et vous demander dans chaque cas quelle somme maximum vous seriez prêt à payer pour que ce scénario soit réalisé. Si aucun de ces scénarios n'est mis en place on est dans le cas de notre situation de référence actuelle c'est à dire que la restauration des étangs va durer plus 50 ans.

C1- Valorisation des scénarios

\begin{tabular}{|l|l|l|l|l|}
\hline Scénarios & 1 & 2 & 3 & 4 \\
\hline Montant & & & & \\
\hline
\end{tabular}

C2-Quel scénario préférez-vous ?.

D1- Etiez-vous certains de vos choix en répondant aux questions sur les scénarios ? :
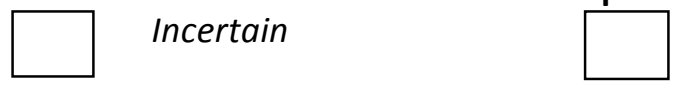

Plutôt certain

Certain

D2. Etes-vous pour ou contre l'idée de contribuer au financement ? Pourquoi ?

\begin{tabular}{|l|l|}
\hline$\square$ & Je ne suis pas contre le fait de contribuer \\
\hline$\square$ & Je ne veux pas payer de nouvelle taxe \\
\hline$\square$ & Je ne crois pas que ma contribution sera réellement utilisée pour la restauration de l'étang du Méjean \\
\hline$\square$ & Ce n'est pas à moi de financer ces travaux \\
\hline
\end{tabular}

D 3- Parmi les aménagements possibles lesquels aimeriez-vous trouver?Choisir 2 réponses par ordre d'importance Choix 1 | |(le plus important) Choix 2 |

\begin{tabular}{|l|ll|}
\hline & A. & Des panneaux explicatifs \\
\hline & B. & Des tables de pique-nique \\
\hline & C. & Des bancs \\
\hline & D. & Des équipements de type parcours sportif \\
\hline & E. & Des huttes pour l'observation des oiseaux \\
\hline & F. & Parcs d'enfants \\
\hline & G. & Autre : précisez \\
\hline & H. & Aucun aménagement : je préfère garder le caractère sauvage \\
\hline
\end{tabular}


Etes d'accord avec les affirmations suivantes?

\begin{tabular}{|l|l|l|l|l|l|l}
\hline \multicolumn{2}{|l}{} & $\begin{array}{l}\text { Tout à } \\
\text { fait } \\
\text { d'accord }\end{array}$ & $\begin{array}{l}\text { Plutôt } \\
\text { d'accord }\end{array}$ & $\begin{array}{l}\text { Plutôt } \\
\text { pas } \\
\text { d'accord }\end{array}$ & $\begin{array}{l}\text { Pas } \\
\text { d'accord } \\
\text { du tout }\end{array}$ & $\begin{array}{l}\text { Ne } \\
\text { sait } \\
\text { pas }\end{array}$ \\
\hline D4 & $\begin{array}{l}\text { Les étangs font partie de notre patrimoine naturel et } \\
\text { ils doivent être préservés pour les générations à venir }\end{array}$ & $\square$ & $\square$ & $\square$ & $\square$ & $\square$ \\
\hline D5 & $\begin{array}{l}\text { Ces scénarios ne correspondent pas à mes attentes de la } \\
\text { restauration de cet étang }\end{array}$ & $\square$ & $\square$ & $\square$ & $\square$ & $\square$ \\
\hline D6 & $\begin{array}{l}\text { Je pense que la restauration envisagée permettra } \\
\text { d'atteindre les objectifs escomptés }\end{array}$ & $\square$ & $\square$ & $\square$ & $\square$ & $\square$ \\
\hline D7 & $\begin{array}{l}\text { Trop d'importance est donnée à la restauration de ces } \\
\text { étangs, il y a d'autres causes prioritaires pour lesquelles } \\
\text { cet argent pourrait être attribué }\end{array}$ & $\square$ & $\square$ & $\square$ & $\square$ & $\square$ \\
\hline D8 & $\begin{array}{l}\text { ll est inutile de restaurer si on sait que tôt ou tard les } \\
\text { étangs seront submergés par la mer }\end{array}$ & $\square$ & $\square$ & $\square$ & $\square$ & \\
\hline
\end{tabular}

D9- Quelle est selon vous l'importance des étangs pour les fonctions suivantes : Choisir 2 réponses par ordre d'importance Choix 1 I__ | (le plus important) Choix 2 |

\begin{tabular}{|ll|}
\hline A. & Gestion du risque inondation \\
\hline B. & Epuration de l'eau \\
\hline C. & Paysage \\
\hline D. & Biodiversité \\
\hline E. & Pêche \\
\hline F. & Chasse \\
\hline G. & Promenades, loisirs \\
\hline
\end{tabular}

D10- A quels enjeux sociétaux consacreriez-vous en priorité les fonds publics ?

Classez les propositions suivantes de la plus prioritaire (1) à la moins prioritaire (5)
a. L'éducation
b. L'environnement.
d. L'emploi / le chômage
c. La sécurité.
e. La santé

D11- Combien donnez-vous par an à des associations de protection de la nature ?

D12- Avez-vous fait des dons à des opérations de solidarité ou des œuvres diverses au cours des 12 derniers mois ?

\begin{tabular}{|l|l|l|l|}
\hline & Oui & $\square$ & Non \\
\hline
\end{tabular}

\section{E) CARACTERISTIQUES PERSONNELLES}

E1- Vous êtes : $\quad \square \quad$ Un homme $\quad \square$ Une femme

E2-Quel est votre âge?

18-30 ans $\square$ 31-45 ans $\square$ 46-65 ans $\square>65$ ans

\section{E3- Êtes-vous :}

Marié(e), Pacsé(e), ou en concubinage $\quad \square \quad$ Célibataire, Veuf(ve) ou Divorcé(e)

E4- Combien d'enfants avez-vous?

E6- Vivez-vous en copropriété?
E5- Dont encore à charge

non $\square$ 
E7- Est-ce que votre activité professionnelle est ou était liée. Plusieurs réponses possibles

$\square$ Au littoral $\square$ A l'environnement $\square$ Aucun

E8- Quelle est votre CSP ?

$\square$ Agriculteur

Ouvrier

$\square$ Artisan, commerçant, chef d'entreprise

Chômeur

$\square$ Cadres et professions supérieures

Étudiant/scolaire

$\square$ Professions intermédiaires

Retraité

$\square \quad$ Employé

Autre : précisez

E9- Quelles sont les ressources mensuelles moyennes totales de votre ménage (y compris les allocations familiales, loyers perçus...) ?

\begin{tabular}{|l|l|l|l|l|l|}
\hline$\square$ & Moins de $700 €$ & $\square$ & De 700 à $1.000 €$ & $\square$ & De 1.000 à $1.300 €$ \\
\hline$\square$ & De 1.300 à $2.000 €$ & $\square$ & De 2.000 à $3.000 €$ & $\square$ & De 3.000 à $4.500 €$ \\
\hline$\square$ & De 4.500 à $6.000 €$ & $\square$ & De 6.000 à $9.000 €$ & $\square$ & Plus de $9.000 €$ \\
\hline$\square$ & Ne sait pas. \\
\hline
\end{tabular}

E10- Des commentaires sur ce questionnaire et/ou sur le projet de restauration de l'étang du Méjean.

Merci de votre compréhension et de votre contribution.

Si vous souhaitez recevoir les résultats de cette enquête, vous pouvez nous laisser vos coordonnées ci-dessous : 


\section{B) PRESENTATION DU PROJET DE RESTAURATION}

Le projet de restauration qui est envisagé repose sur la reconstitution des herbiers au fond de l'étang car ces herbiers favorisent à une amélioration de la qualité de l'eau et le développement de la biodiversité. Un étang avec des vastes herbiers présente un habitat pour les canards, les cygnes sauvages et les hippocampes qui sont des espèces emblématiques des lagunes de la région. Ces améliorations du milieu bénéficieront aussi directement à la population car il y aura moins de mauvaises odeurs à proximité des étangs, il sera plus agréable de s'y promener et on pourra observer plus d'oiseaux.

- Dans une première phase (pendant 4 à 5 ans) il faut favoriser le développement de macro-algues qui seront récoltées et emportées, ce qui diminuera la pollution accumulée dans le sédiment. Cela permet de créer des conditions propices au développement ultérieur de l'herbier.

- Dans une seconde phase, il s'agit d'implanter des herbiers pour favoriser une couverture optimale de la surface.

Plusieurs options sont possibles pour réaliser cette restauration. Ce sont ces options que nous allons vous présenter et vous demander d'évaluer.

Premièrement on peut fixer plusieurs objectifs de reconstitutions des herbiers. Plus il y a d'herbiers et plus la qualité de l'eau et de la biodiversité sera grande. Par contre la présence d'herbiers ne permet pas aux flamands roses d'avoir un accès facile à leurs proies dans le sédiment. Donc plus il y a $d^{\prime}$ 'herbiers et plus on peut s'attendre à une diversité d'espèces, notamment des cygnes, des canards et des hippocampes, mais à moins de flamants roses.

Trois niveaux de couverture sont envisagés:

- FAIBLE (beaucoup de flamants, environnement non favorable à la présence de cygnes et d'hippocampes, qualité de l'eau améliorée mais ne remplit pas les critères de bon état de la Directive Cadre sur l'Eau (DCE)

- MOYEN (moins de flamants, environnement peu favorable à la présence de d'hippocampes, de cygnes ou de canards, qualité de l'eau améliorée, mais risque d'être considérée pas encore assez bonne selon les critères de la DCE)

- ELEVE (peu de flamants, environnement favorable à l'installation d'hippocampes, de cygnes et de canards, bonne qualité de l'eau correspondant aux critères de la DCE)

Le développement de cette biodiversité et notamment des espèces d'oiseaux va rendre les étangs plus attractifs pour les promeneurs. On peut donc envisager par exemple d'aménager des sentiers de promenades, des postes d'observation des oiseaux. Cependant il ne faut pas que les promeneurs fassent fuir les oiseaux. Il faut pouvoir gérer le dérangement occasionné par ces promeneurs (bruit, piétinent des nids...).

Trois choix d'aménagement ont donc aussi été retenus.

- Conservation des sentiers actuels comme moyen d'accès de la zone. 
- Multiplier le nombre de sentiers pour favoriser l'accessibilité du site et les promenades mais avec un effet de dérangement pour les oiseaux

- Augmenter les sentiers mais avec des aménagements qui permettent de limiter le dérangement des oiseaux

Enfin bien sûr, ces différentes options vont avoir un impact sur le coût du projet.

Il s'agit ici de savoir combien vous seriez prêt à payer pour plusieurs scénarios possibles qui combinent les différentes options de couverture des herbiers et d'aménagement. La réalisation du projet pourrait être en partie financé par des fonds publics (européens et régionaux) car ce sera un des projets les plus importants de restauration des herbiers en France, mais il aurait aussi des répercussions sur votre facture d'eau qui comprend une partie de taxe de lutte contre la pollution (autrefois appelée taxe d'assainissement) collectée par l'Agence de l'eau ou sur la taxe de séjour des touristes.

Pour vous permettre de situer les ordres de grandeur, la taxe est actuellement de 0,28 euros par M3 et la consommation nationale de référence pour un ménage de 2 personnes est de $130 \mathrm{~m} 3 / \mathrm{an}$. Le montant de la taxe correspondante est donc de 38 euros par an.

\section{A titre indicatif, vous pouvez vous référer à votre dernière facture d'eau (consommation semestrielle) si vous l'avez en mémoire.}

Nous allons maintenant vous présenter 4 scénarios qui permettent de combiner les différentes options et vous demander dans chaque cas quelle somme maximum vous seriez prêt à payer pour que ce scénario soit réalisé. Si aucun de ces scénarios n'est mis en place on est dans le cas de notre situation de référence actuelle c'est à dire que la restauration des étangs va durer plus 50 ans. 


\section{Scénario 1}

\section{Faible couverture de l'herbier}

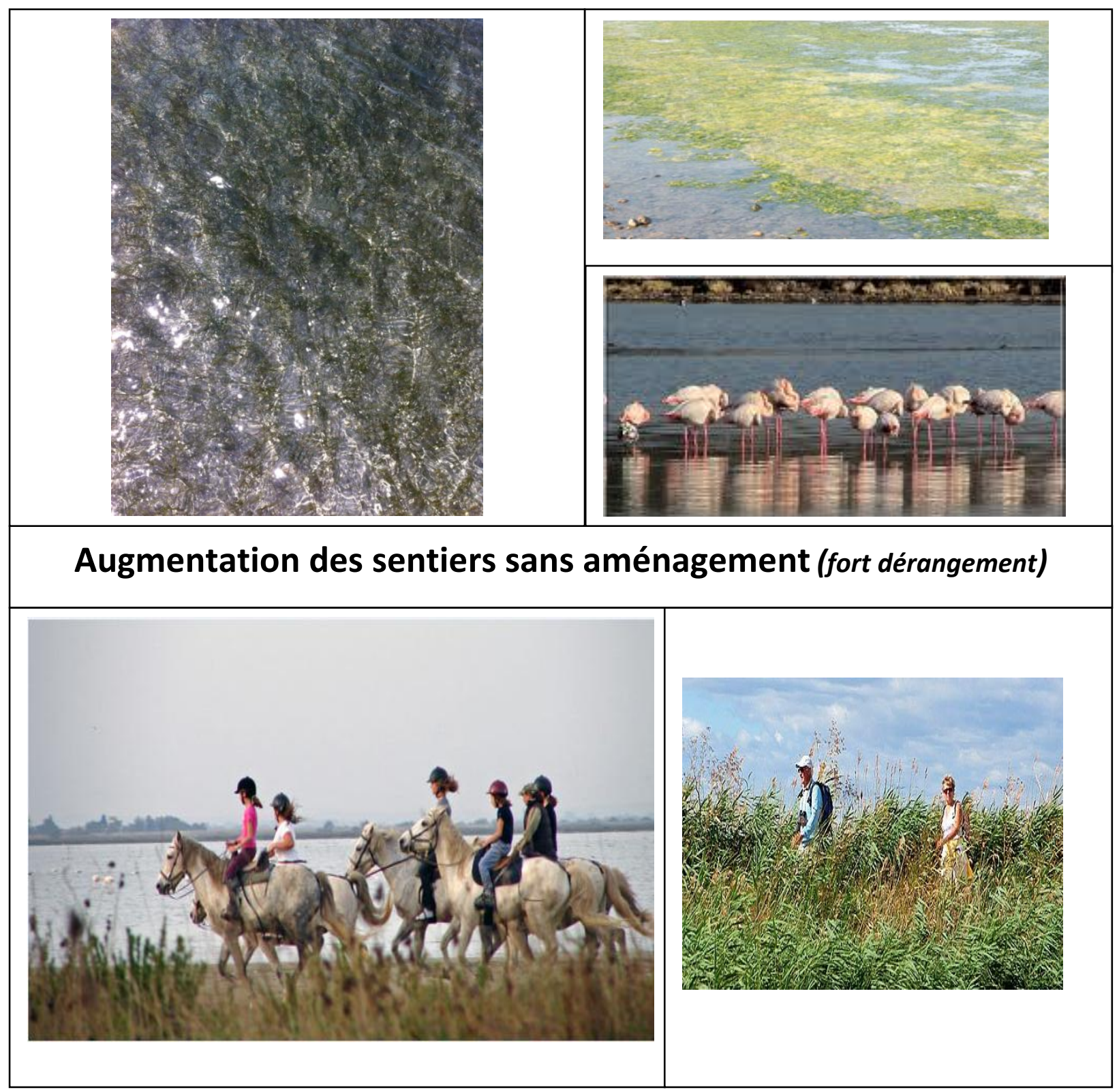

Montant (en $€ /$ an pendant 10 ans)

$\begin{array}{lllllllllllll}0 & 5 & 10 & 15 & 20 & 25 & 30 & 35 & 40 & 45 & 50 & 55 & 60\end{array}$

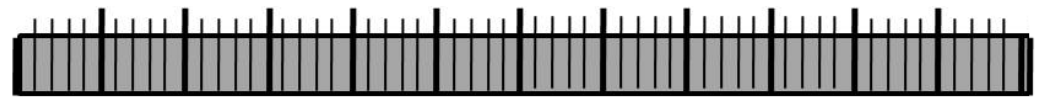




\section{Scénario 2}

Couverture intermédiaire de l'herbier

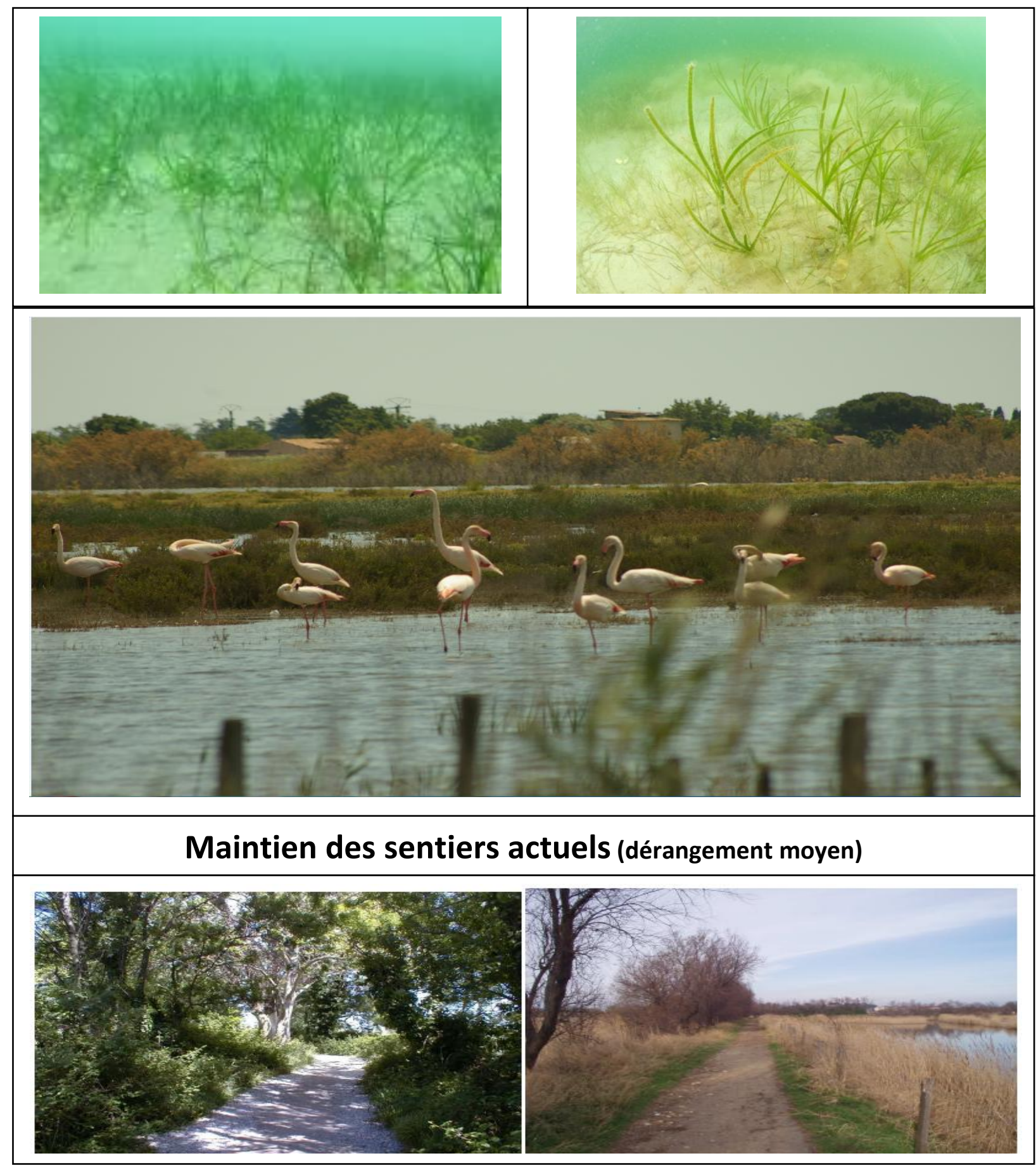

Montant (en $€ /$ an pendant 10 ans)

$\begin{array}{lllllllllllll}0 & 5 & 10 & 15 & 20 & 25 & 30 & 35 & 40 & 45 & 50 & 55 & 60\end{array}$

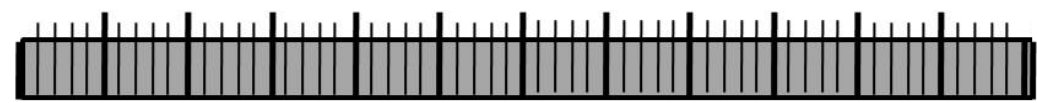




\section{Scénario 3}

\section{Couverture intermédiaire de l'herbier}

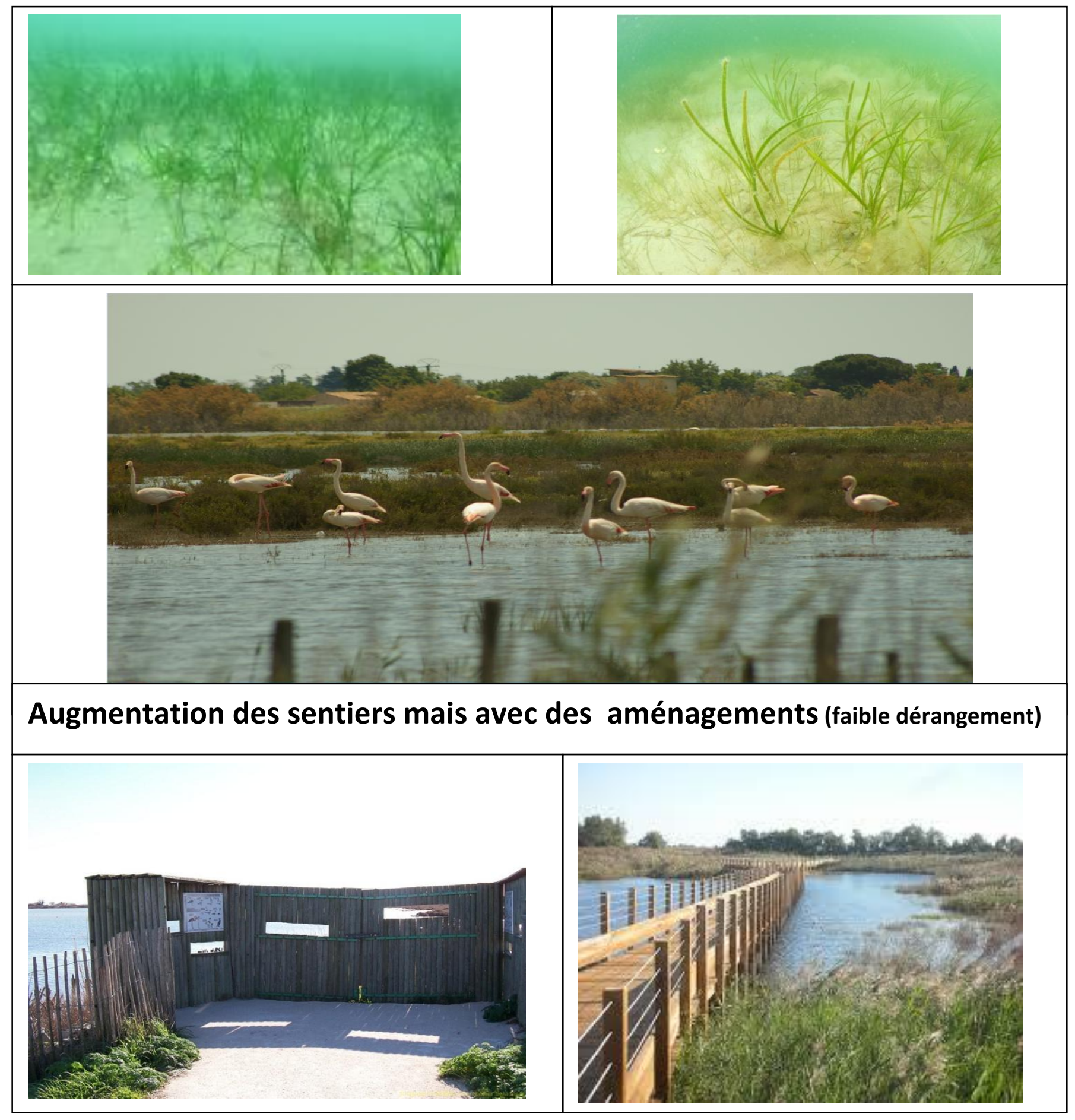

Montant (en $€ /$ an pendant 10 ans)

$\begin{array}{lllllllllllll}0 & 5 & 10 & 15 & 20 & 25 & 30 & 35 & 40 & 45 & 50 & 55 & 60\end{array}$

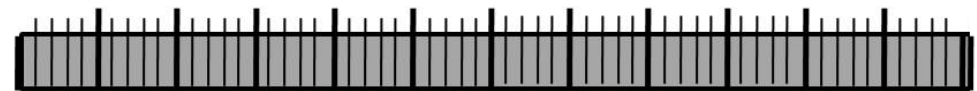




\section{Scénario 4}

\section{Forte couverture de l'herbier}

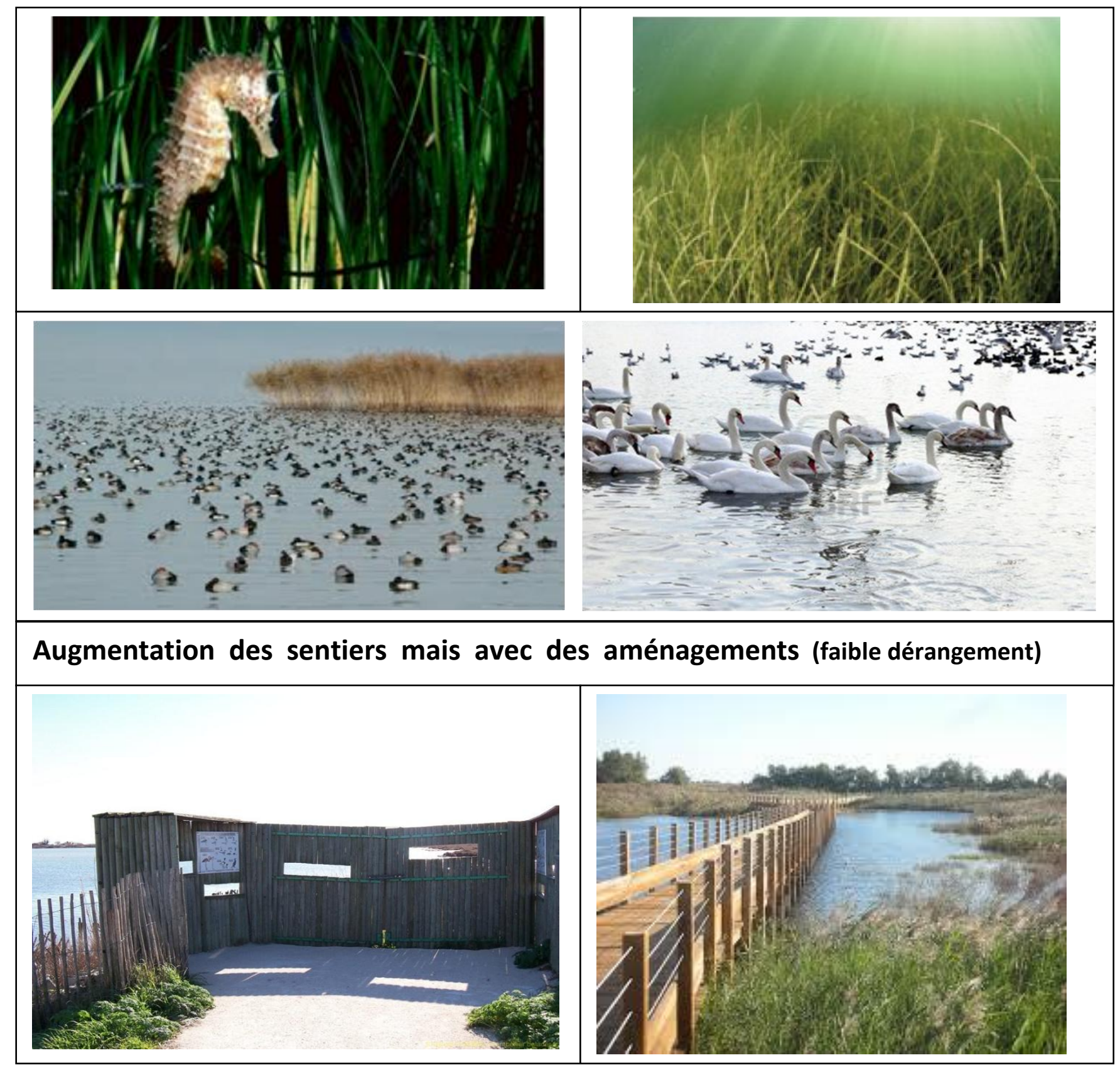

Montant (en $€ /$ an pendant 10 ans)

$\begin{array}{lllllllllllll}0 & 5 & 10 & 15 & 20 & 25 & 30 & 35 & 40 & 45 & 50 & 55 & 60\end{array}$

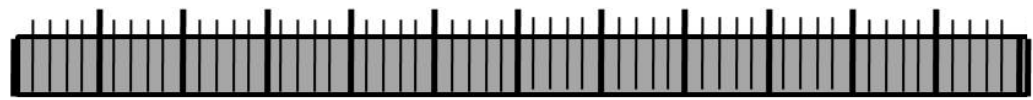




\title{
Enquête sur les préférences pour la restauration des étangs palavasiens
}

\author{
Version TOURISTES ET NAVIGATION FLUVIALE
}

Depuis les années 1960, les étangs palavasiens ont été dégradés par des apports excessifs d'azote et de phosphore. Ces apports principalement issus de la station d'épuration de Montpellier ont entrainé une dégradation du milieu et de la qualité de l'eau. C'est l'étang du Méjean qui est le plus touché. L'agglomération de Montpellier en collaboration avec La Région et l'Agence de l'Eau ont financé la construction fin 2005 d'un émissaire en mer qui réduit considérablement l'impact de la station d'épuration sur les étangs. La qualité de l'eau s'est donc fortement améliorée. Cependant de grandes quantités d'azote et de phosphore ont été stockées dans les sédiments et sont régulièrement larguées dans le milieu. L'atteinte d'un bon état écologique, comme le réclame la directive européenne sur l'eau va donc prendre beaucoup de temps (plus de 50 ans). Selon les experts, il est possible de raccourcir ce délai de façon importante par la restauration des herbiers dans l'étang. Plusieurs options sont possibles. Cette enquête vise à identifier vos préférences par rapport à ces options qui auront des coûts et des bénéfices différents pour la société.

Cette enquête est réalisée par le CNRS et l'Université de Montpellier en partenariat avec le syndicat de gestion des étangs palavasiens (SIEL). Elle vise à recueillir les préférences des habitants et des touristes sur les modalités d'amélioration de la qualité des eaux des étangs palavasiens.

Les données individuelles ou opinions recueillies dans cette enquête sont strictement confidentielles et seront uniquement utilisées dans un but de recherche. Elles feront uniquement l'objet d'un traitement statistique. En aucun cas, elles ne pourront être utilisées par les administrations ou les collectivités territoriales.

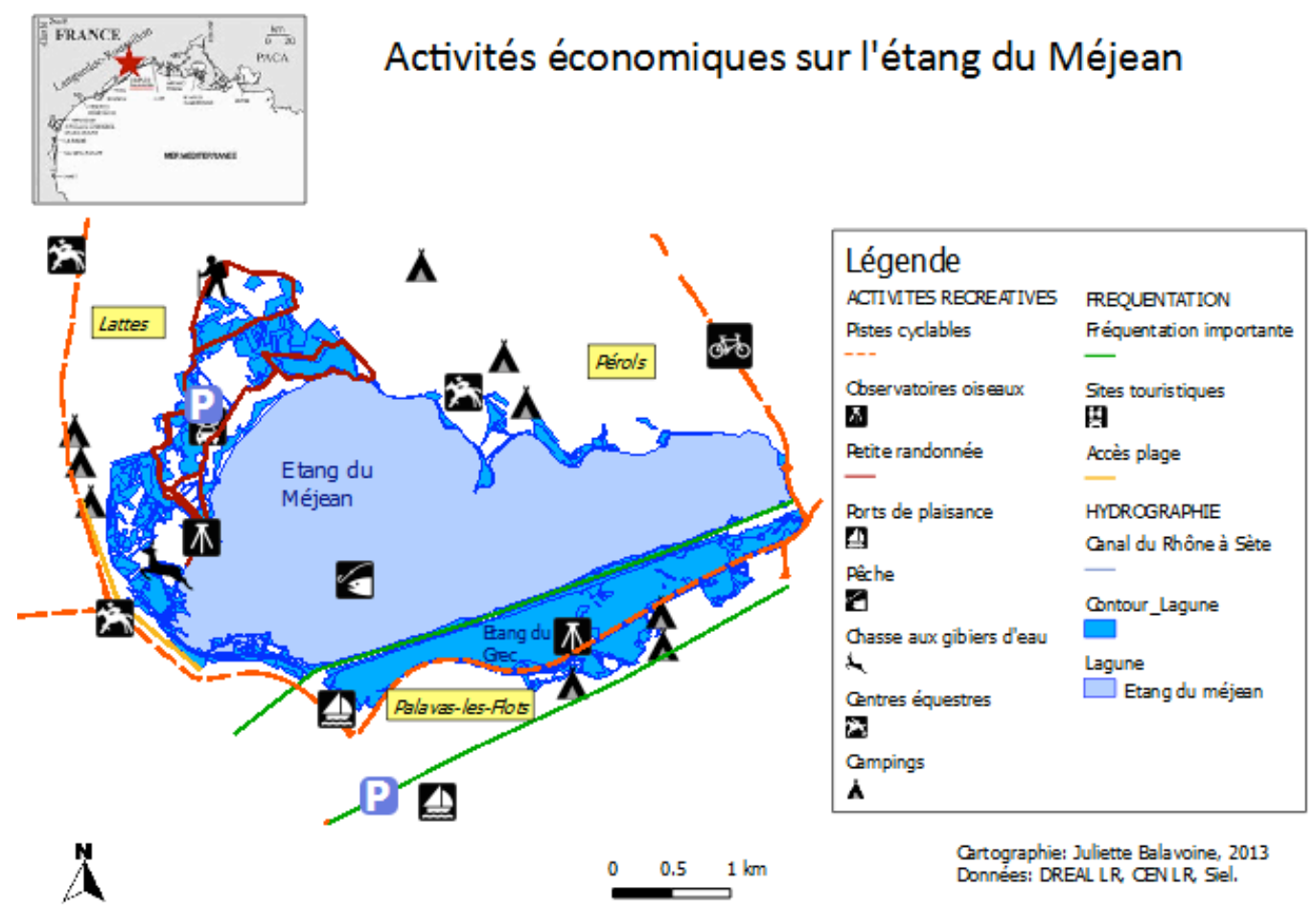


A1- Dans quelle région ou pays résidez-vous habituellement?

A2- Etes-vous :

De passage

En séjour de vacances

Durée :

A3 : Revenez-vous régulièrement dans la région de Montpellier ?

\begin{tabular}{|l|l|l|l|l|l|l|}
\hline Non & & Oui & & Chaque année & & $\begin{array}{l}\text { Plusieurs fois } \\
\text { par an }\end{array}$ \\
\hline
\end{tabular}

A4 : Comment êtes-vous hébergé ?

\begin{tabular}{|c|c|c|c|}
\hline Invité (famille, amis) & Camping & Hôtel & $\begin{array}{l}\text { Résidence } \\
\text { secondaire }\end{array}$ \\
\hline
\end{tabular}

A5- Etes-vous en vacances :

\begin{tabular}{|l|l|l|l|l|} 
Seul & & En famille & & En couple \\
\hline
\end{tabular}

A6- Etes-vous originaire de la région Languedoc-Roussillon ? $\square$ Oui $\square$ Non

A7- Connaissiez-vous l'existence des étangs palavasiens avant cette enquête ?

$\square$ Oui j'y suis déjà allé $\square$ Oui j'en ai entendu parler $\square$ Non (-> question A-9)

A8- Quelle est la fréquence de votre fréquentation des étangs palavasiens ? (préciser qu'il ne s'agit pas seulement de passer devant mais de s'arrêter et au moins descendre de voiture)

\begin{tabular}{|l|l|l|l|l|l|l|}
\hline Moins 1 fois/ an & 1 fois /an & 1 à 2 fois/an & & Plus de 2 fois/ an \\
\hline
\end{tabular}

A9-Dans quelle zone du Méjean allez-vous en priorité ? (voir la carte)

Piste cyclable

$\square$ chemin de halage

sentier de la maison de la nature

A10-Si vous fréquentez les zones des étangs quelles sont les activités que vous pratiquez ?

\begin{tabular}{|l|l|l|l|}
\hline & Promenade à pied, découverte de la nature & & Sports nautiques \\
\hline & Promenade à vélo & & Pêche de loisir \\
\hline & Promenade à cheval & & Chasse \\
\hline Promenade du chien & & Autre : précisez \\
\hline
\end{tabular}

A111- Si non, pourquoi ne fréquentez-vous pas les zones des étangs?

\begin{tabular}{|l|l|}
\hline & Ça ne m'intéresse pas \\
\hline & Ils sont trop loin \\
\hline & Ils ne sont pas accessibles \\
\hline & Je ne connais pas ces étangs \\
\hline & Ils sont trop pollués / odeurs gênantes \\
\hline & Autres précisez \\
\hline
\end{tabular}

A13- Vous arrive-t-il de vous rendre près d'autres étangs

Oui

Non 


\section{B) PRESENTATION DU PROJET DE RESTAURATION}

Le projet de restauration qui est envisagé repose sur la reconstitution des herbiers au fonds de l'étang (monter photo) car ces herbiers favorisent à une amélioration de la qualité de l'eau et le développement de la biodiversité. Un étang avec des vastes herbiers présente un habitat pour les canards, les cygnes sauvages et les hippocampes qui sont des espèces emblématiques des lagunes de la région. Ces améliorations du milieu bénéficieront aussi directement à la population car il y aura moins de mauvaises odeurs à proximité des étangs, il sera plus agréable de s'y promener et on pourra observer plus d'oiseaux.

- Dans une première phase (pendant 4 à 5 ans) il faut favoriser le développement de macro-algues qu'il faudra récolter et exporter. Ces algues diminuent la pollution accumulée dans le sédiment. Cela permet de créer des conditions propices au développement de l'herbier.

- Dans une seconde phase, il s'agit d'implanter des herbiers pour favoriser une couverture optimale de la surface.

Plusieurs options sont possibles pour réaliser cette restauration. Ce sont ces options que nous allons vous présenter et vous demander d'évaluer.

Premièrement on peut fixer plusieurs objectifs de reconstitutions des herbiers. Plus il y a d'herbiers et plus la qualité de l'eau et de la biodiversité sera grande. Par contre la présence d'herbiers ne permet pas aux flamands roses d'avoir un accès facile à leurs proies dans le sédiment. Donc plus il y a d'herbiers et plus on peut s'attendre à une diversité d'espèces, notamment des cygnes, des canards et des hippocampes, mais à moins de flamants roses.

Trois niveaux de couverture sont envisagés:

- FAIBLE (beaucoup de flamants, environnement non favorable à la présence de cygnes, canards, hippocampes, qualité de l'eau améliorée mais ne remplit pas les critères de bonne état de la Directive Cadre sur l'Eau (DCE)

- MOYEN (moins de flamants, environnement peu favorable à la présence d'hippocampes, de cygne ou de canards, qualité de l'eau améliorée, mais risque d'être considérée pas encore assez bonne selon les critères de la DCE)

- ELEVE (peu de flamants, environnement favorable à l'installation d'hippocampes, de cygnes et de canards, bonne qualité de l'eau correspondant aux critères de la DCE)

Le développement de cette biodiversité et notamment des espèces d'oiseaux va rendre les étangs plus attractifs pour les promeneurs. On peut donc envisager par exemple d'aménager des sentiers de promenades, des postes d'observation des oiseaux. Cependant il ne faut pas que les promeneurs fassent fuir les oiseaux. II faut pouvoir gérer le dérangement occasionné par ces promeneurs (bruit, piétinent des nids...).

Trois choix d'aménagement ont donc aussi été retenus.

- Conservation des sentiers actuels comme moyen d'accès de la zone. 
- Multiplier le nombre de sentiers pour favoriser l'accessibilité du site et les promenades mais avec un effet de dérangement pour les oiseaux

- Augmenter les sentiers mais avec des aménagements qui permettent de limiter le dérangement des oiseaux

Enfin bien sûr, ces différentes options vont avoir un impact sur le coût du projet.

Il s'agit ici de savoir combien vous seriez prêt à payer pour plusieurs scénarios possibles qui combinent les différentes options de couverture des herbiers et d'aménagement. La réalisation du projet serait en partie financée par des fonds publics (européens et régionaux) car ce sera un des projets les plus importants de restauration des herbiers en France, mais il aurait aussi des répercussions sur votre taxe de séjour (collectée dans la facture de votre séjour selon votre mode d'hébergement).

Pour vous donner un ordre de grandeur, la taxe de séjour par nuitée et par personne est à Montpellier de 0,35 euros. Soit 1,40 euros pour un couple avec 2 enfants. Si vous résidez une semaine, votre taxe est de 9,80 euros.

Nous allons maintenant vous présenter 4 scénarios qui permettent de combiner les différentes options et vous demander dans chaque cas quelle somme maximum vous seriez prêt à payer pour que ce scénario soit réalisé. Si aucun de ces scénarios n'est mis en place on est dans le cas de notre situation de référence actuelle c'est à dire que la restauration des étangs va durer plus de 50 ans.

\section{C1- Valorisation des scénarios}

\begin{tabular}{|l|l|l|l|l|}
\hline Scénarios & 1 & 2 & 3 & 4 \\
\hline Montant & & & & \\
\hline
\end{tabular}

C2-Quel scénario préférez-vous ?.

D1- Etiez-vous certains de vos choix en répondant aux questions sur les scénarios ? : Incertain Plutôt certain

Certain

D2. Etes-vous pour ou contre l'idée de contribuer au financement ? Pourquoi ?

\begin{tabular}{|l|l|}
\hline$\square$ & Je ne suis pas contre le fait de contribuer \\
\hline$\square$ & Je ne veux pas payer de nouvelle taxe \\
\hline$\square$ & Je ne crois pas que ma contribution sera réellement utilisée pour la restauration de l'étang du Méjean \\
\hline$\square$ & Ce n'est pas à moi de financer ces travaux \\
\hline
\end{tabular}


D 3- Parmi les aménagements possibles lesquels aimeriez-vous trouver?

Choisir 2 réponses par ordre d'importance Choix $1 \mid \ldots$ _(le plus important) Choix 2

\begin{tabular}{|l|ll|}
\hline & A. & Des panneaux explicatifs \\
\hline & B. & Des tables de pique-nique \\
\hline & C. & Des bancs \\
\hline & D. & Des équipements de type parcours sportif \\
\hline & E. & Des huttes pour l'observation des oiseaux \\
\hline & F. & Parcs d'enfants \\
\hline & G. & Autre : précisez \\
\hline & H. & Aucun aménagement : je préfère garder le caractère sauvage \\
\hline
\end{tabular}

Etes d'accord avec les affirmations suivantes?

\begin{tabular}{|l|l|l|l|l|l|l|}
\hline \multicolumn{2}{|l}{} & $\begin{array}{l}\text { Tout à } \\
\text { fait } \\
\text { d'accord }\end{array}$ & $\begin{array}{l}\text { Plutôt } \\
\text { d'accord }\end{array}$ & $\begin{array}{l}\text { Plutôt } \\
\text { pas } \\
\text { d'accord }\end{array}$ & $\begin{array}{l}\text { Pas } \\
\text { d'accord } \\
\text { du tout }\end{array}$ & $\begin{array}{l}\text { Ne } \\
\text { sait } \\
\text { pas }\end{array}$ \\
\hline D4 & $\begin{array}{l}\text { Les étangs font partie de notre patrimoine naturel et } \\
\text { ils doivent être préservés pour les générations à venir }\end{array}$ & $\square$ & $\square$ & $\square$ & $\square$ & $\square$ \\
\hline D5 & $\begin{array}{l}\text { Ces scénarios ne correspondent pas à mes attentes de la } \\
\text { restauration de cet étang }\end{array}$ & $\square$ & $\square$ & $\square$ & $\square$ & $\square$ \\
\hline D6 & $\begin{array}{l}\text { Je pense que la restauration envisagée permettra } \\
\text { d'atteindre les objectifs escomptés }\end{array}$ & $\square$ & $\square$ & $\square$ & $\square$ & $\square$ \\
\hline D7 & $\begin{array}{l}\text { Trop d'importance est donnée à la restauration de ces } \\
\text { étangs, il y a d'autres causes prioritaires pour lesquelles } \\
\text { cet argent pourrait être attribué }\end{array}$ & $\square$ & $\square$ & $\square$ & $\square$ & $\square$ \\
\hline D8 & $\begin{array}{l}\text { Il est inutile de restaurer si on sait que tôt ou tard les } \\
\text { étangs seront submergés par la mer }\end{array}$ & $\square$ & $\square$ & $\square$ & $\square$ & \\
\hline
\end{tabular}

D9- Quelle est selon vous l'importance des étangs pour les fonctions suivantes :

Choisir 2 réponses par ordre d'importance Choix 1 I__ (le plus important) Choix 2

\begin{tabular}{|ll|}
\hline A. & Gestion du risque inondation \\
\hline B. & Epuration de l'eau \\
\hline C. & Paysage \\
\hline D. & Biodiversité \\
\hline E. & Pêche \\
\hline F. & Chasse \\
\hline G. & Promenades, loisirs \\
\hline
\end{tabular}

D10- A quels enjeux sociétaux consacreriez-vous en priorité les fonds publics ?

Classez les propositions suivantes de la plus prioritaire (1) à la moins prioritaire (5)
a. L'éducation
b. L'environnement.
d. L'emploi / le chômage
c. La sécurité.
e. La santé. 
D11- Combien donnez-vous par an à des associations de protection de la nature ?

D12- Avez-vous fait des dons à des opérations de solidarité ou des œuvres

diverses au cours des 12 derniers mois ?

\section{E) CARACTERISTIQUES PERSONNELLES}

E1- Vous êtes : $\quad \square \quad$ Un homme $\quad \square$ Une femme

E2-Quel est votre âge?
18-30 ans
$31-45$ ans
$46-65$ ans $>65$ ans

E3- Êtes-vous :

Marié(e), Pacsé(e), ou en concubinage $\quad \square \quad$ Célibataire, Veuf(ve) ou Divorcé(e)

E4- Combien d'enfants avez-vous? E5- Dont encore à charge

E5- Vivez-vous en copropriété? Oui non $\square$

E6- Est-ce que votre activité professionnelle est ou était liée. Plusieurs réponses possibles

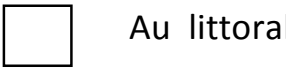

A l'environnement Aucun

E7- Quelle est votre CSP ?

$\square \quad$ Agriculteur

$\square \quad$ Artisan, commerçant, chef d'entreprise

$\square \quad$ Étudiant/scolaire

$\square \quad$ Cadres et professions supérieures Retraité

$\square \quad$ Professions intermédiaires

Autre : précisez

$\square \quad$ Employé

$\square \quad$ Ouvrier

$\square$ Chômeur

E8- Quelles sont les ressources mensuelles moyennes totales de votre ménage (y compris les allocations familiales, loyers perçus...) ?

\begin{tabular}{|l|l|l|l|l|l|}
\hline$\square$ & Moins de $700 €$ & $\square$ & De 700 à $1.000 €$ & $\square$ & De 1.000 à $1.300 €$ \\
\hline$\square$ & De 1.300 à $2.000 €$ & $\square$ & De 2.000 à $3.000 €$ & $\square$ & De 3.000 à $4.500 €$ \\
\hline$\square$ & De 4.500 à $6.000 €$ & $\square$ & De 6.000 à $9.000 €$ & $\square$ & Plus de $9.000 €$ \\
\hline$\square$ & Ne sait pas. \\
\hline
\end{tabular}

E9- Des commentaires sur ce questionnaire et/ou sur le projet de restauration de l'étang du Méjean

Merci de votre compréhension et de votre contribution.

Si vous souhaitez recevoir les résultats de cette enquête, vous pouvez nous laisser vos coordonnées ci-dessous : 


\section{B) PRESENTATION DU PROJET DE RESTAURATION}

Le projet de restauration qui est envisagé repose sur la reconstitution des herbiers au fond de l'étang car ces herbiers favorisent à une amélioration de la qualité de l'eau et le développement de la biodiversité. Un étang avec des vastes herbiers présente un habitat pour les canards, les cygnes sauvages et les hippocampes qui sont des espèces emblématiques des lagunes de la région. Ces améliorations du milieu bénéficieront aussi directement à la population car il y aura moins de mauvaises odeurs à proximité des étangs, il sera plus agréable de s'y promener et on pourra observer plus d'oiseaux.

- Dans une première phase (pendant 4 à 5 ans) il faut favoriser le développement de macro-algues qui seront récoltées et emportées, ce qui diminuera la pollution accumulée dans le sédiment. Cela permet de créer des conditions propices au développement ultérieur de l'herbier.

- Dans une seconde phase, il s'agit d'implanter des herbiers pour favoriser une couverture optimale de la surface.

Plusieurs options sont possibles pour réaliser cette restauration. Ce sont ces options que nous allons vous présenter et vous demander d'évaluer.

Premièrement on peut fixer plusieurs objectifs de reconstitutions des herbiers. Plus il y a d'herbiers et plus la qualité de l'eau et de la biodiversité sera grande. Par contre la présence d'herbiers ne permet pas aux flamands roses d'avoir un accès facile à leurs proies dans le sédiment. Donc plus il y a $d^{\prime}$ 'herbiers et plus on peut s'attendre à une diversité d'espèces, notamment des cygnes, des canards et des hippocampes, mais à moins de flamants roses.

Trois niveaux de couverture sont envisagés:

- FAIBLE (beaucoup de flamants, environnement non favorable à la présence de cygnes et d'hippocampes, qualité de l'eau améliorée mais ne remplit pas les critères de bon état de la Directive Cadre sur l'Eau (DCE)

- MOYEN (moins de flamants, environnement peu favorable à la présence de d'hippocampes, de cygnes ou de canards, qualité de l'eau améliorée, mais risque d'être considérée pas encore assez bonne selon les critères de la DCE)

- ELEVE (peu de flamants, environnement favorable à l'installation d'hippocampes, de cygnes et de canards, bonne qualité de l'eau correspondant aux critères de la DCE)

Le développement de cette biodiversité et notamment des espèces d'oiseaux va rendre les étangs plus attractifs pour les promeneurs. On peut donc envisager par exemple d'aménager des sentiers de promenades, des postes d'observation des oiseaux. Cependant il ne faut pas que les promeneurs fassent fuir les oiseaux. Il faut pouvoir gérer le dérangement occasionné par ces promeneurs (bruit, piétinent des nids...).

Trois choix d'aménagement ont donc aussi été retenus.

- Conservation des sentiers actuels comme moyen d'accès de la zone. 


\section{Scénario 1}

\section{Faible couverture de l'herbier}

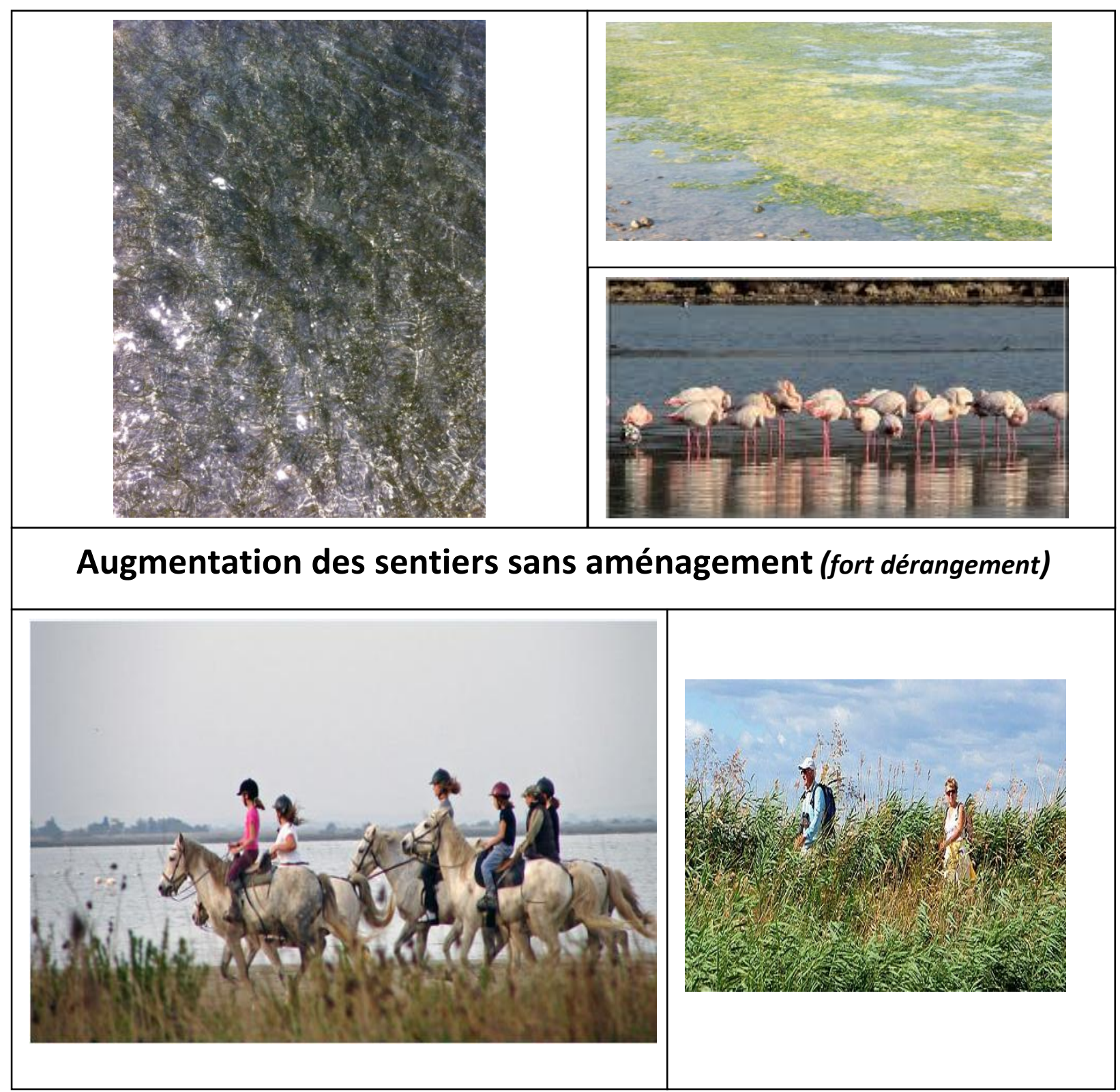

Montant (en $€ /$ semaine)

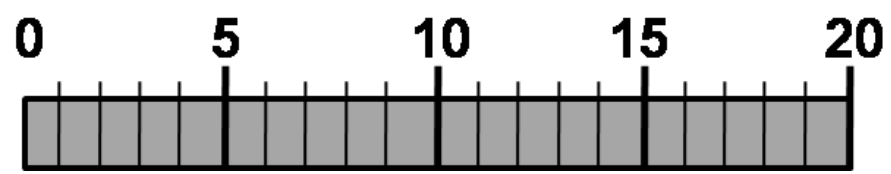




\section{Scénario 2}

Couverture intermédiaire de l'herbier
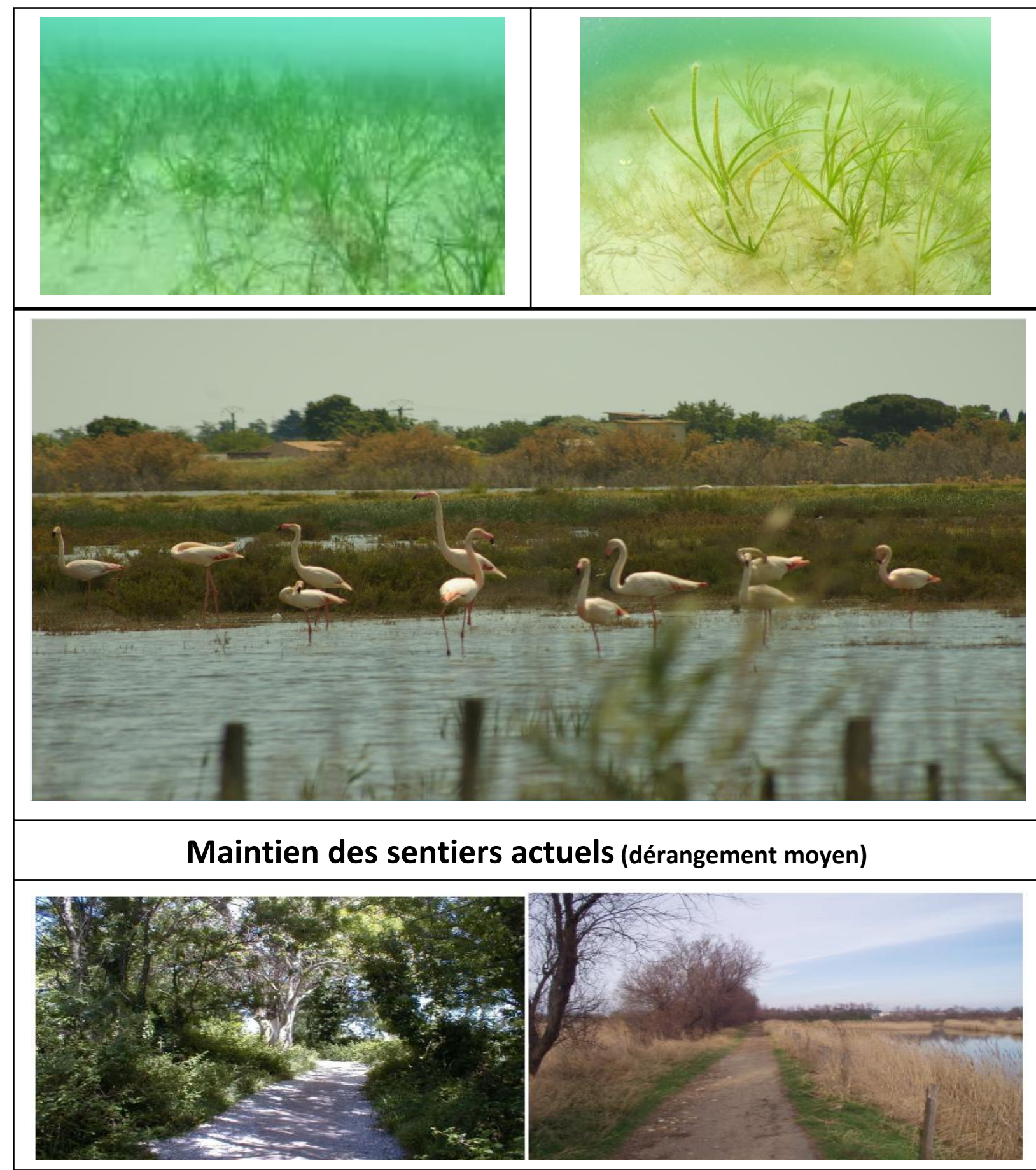

Montant (en $€ /$ semaine)

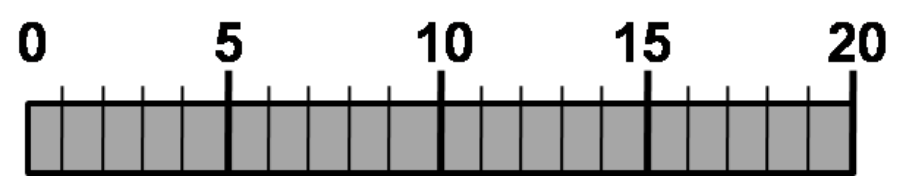




\section{Scénario 3}

\section{Couverture intermédiaire de l'herbier}

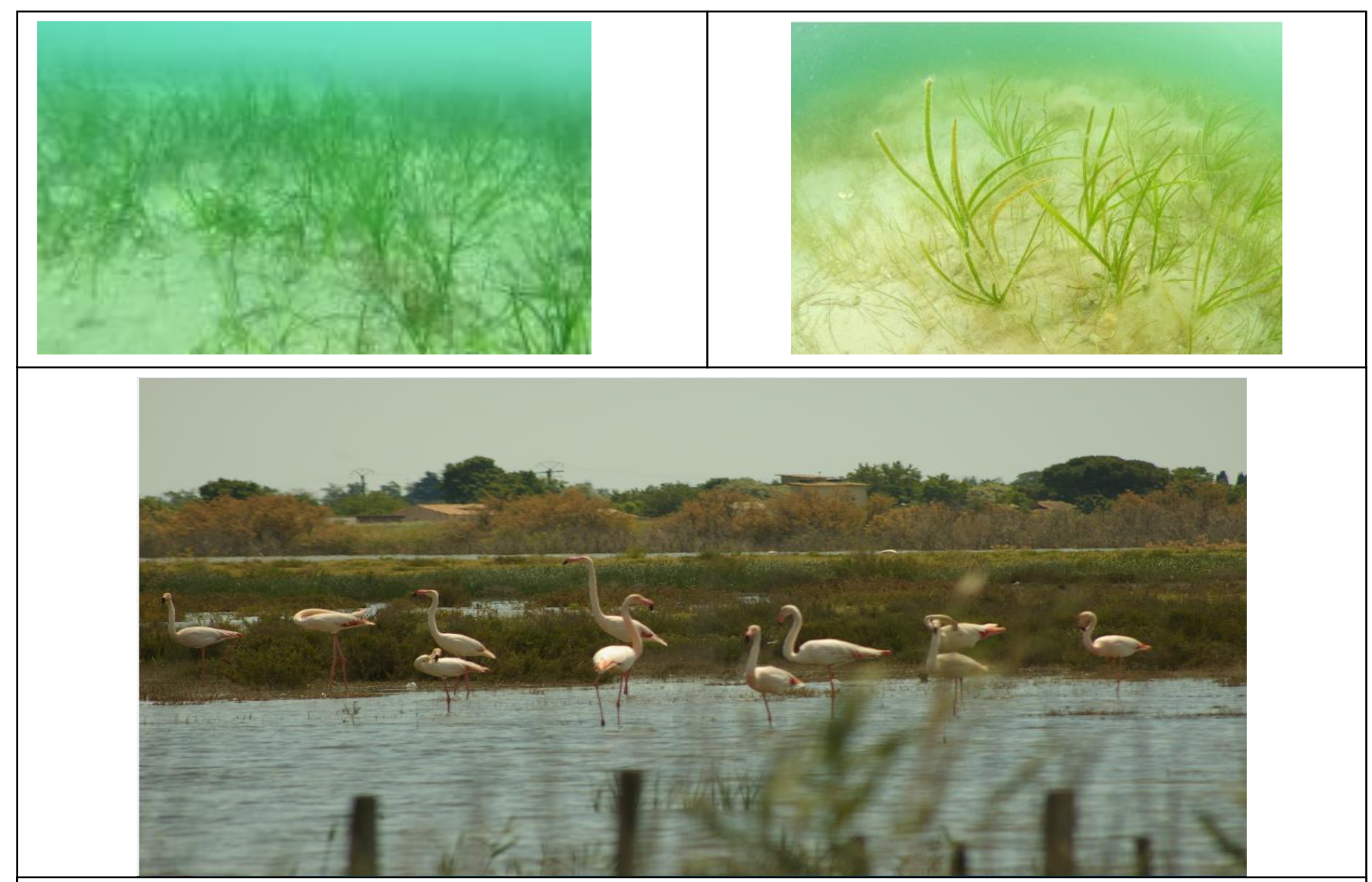

Augmentation des sentiers mais avec des aménagements (faible dérangement)
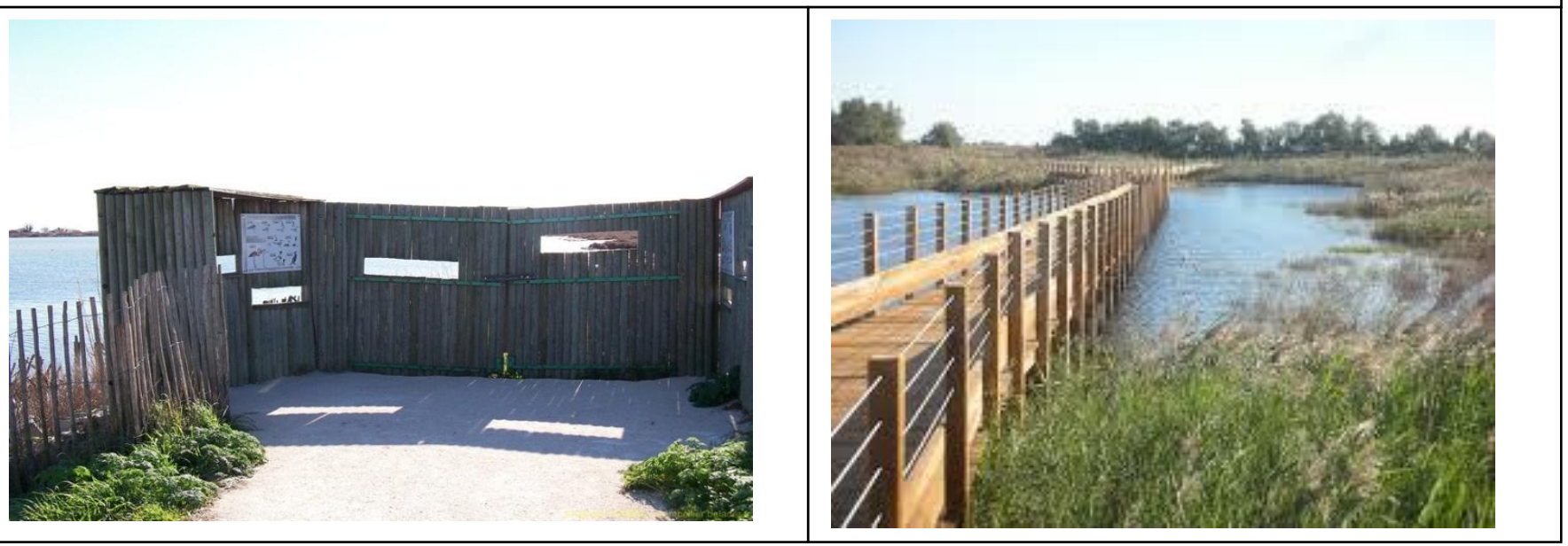

Montant (en $€ /$ semaine)

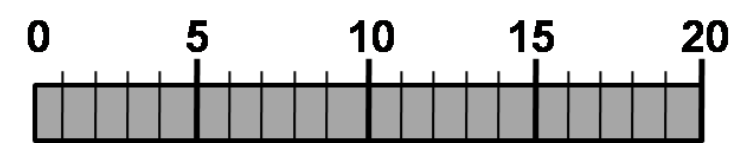




\section{Scénario 4}

\section{Forte couverture de l'herbier}

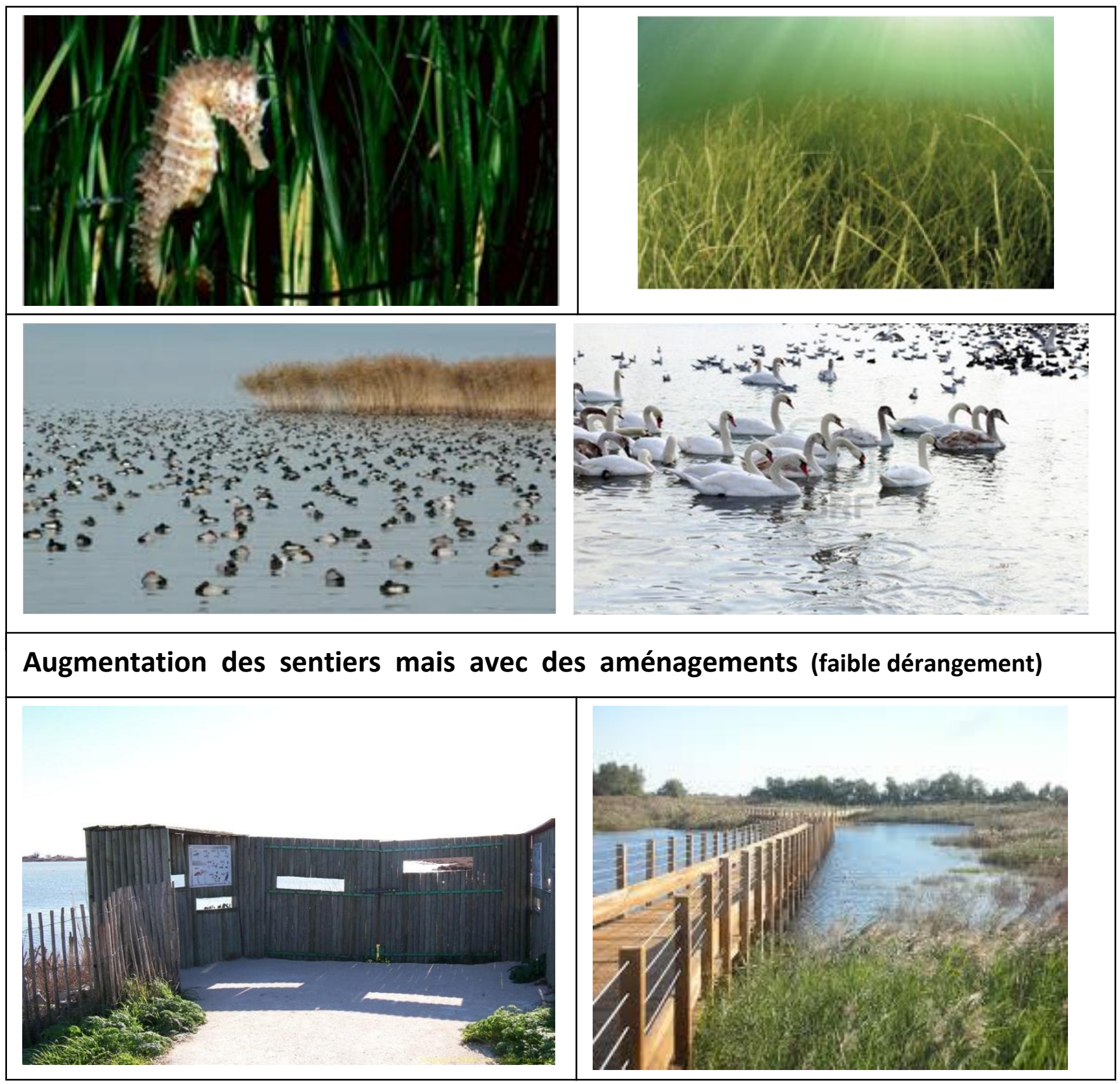

Montant (en $€ /$ semaine)

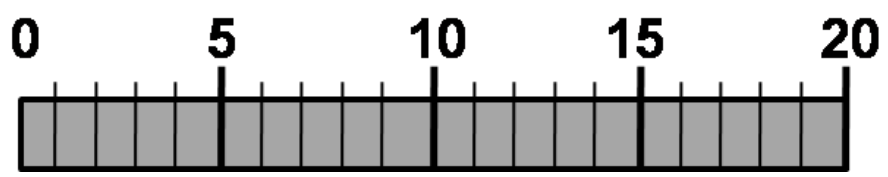




\section{Supplementary Tables}

Table S1: Names and disciplines of the authors and specialisation of the experts of the focus group and those consulted separately.

\begin{tabular}{|c|c|c|c|}
\hline \multirow{3}{*}{ Authors } & & speciality & function \\
\hline & Rutger de Wit & $\begin{array}{l}\text { biogeochemistry, coastal lagoon } \\
\text { ecology }\end{array}$ & researcher \\
\hline & Hélène Rey-Valette & environmental economics & $\begin{array}{l}\text { assistant } \\
\text { prof }\end{array}$ \\
\hline \multirow{9}{*}{ Focus group participants } & Juliette Balavoine & marine ecology & $\begin{array}{l}\text { Master } \\
\text { student }\end{array}$ \\
\hline & Vincent Ouisse & Benthic ecologist & researcher \\
\hline & Robert Lifran & environmental economics & researcher \\
\hline & Amandine Leruste & phytoplankton ecology & $\begin{array}{l}\text { PhD } \\
\text { student }\end{array}$ \\
\hline & Béatrice Bec & phytoplankton ecology & $\begin{array}{l}\text { assistant } \\
\text { prof }\end{array}$ \\
\hline & Daniel Grzebyk & phytoplankton ecology & researcher \\
\hline & Dominique Munaron & chemical conrtaminants & researcher \\
\hline & Sonia Bertrand & $\begin{array}{l}\text { science communication and } \\
\text { outreach }\end{array}$ & agent \\
\hline & Laurent Mauragues & water agency & agent \\
\hline
\end{tabular}


Matthew Hebert

Sandrine Le Noc

Seperately interviewed experts

Francesca Rossi
Patrick Grillas
Brigitte Poulin
Nathalie Barre

Local lagoon managers

J uliette Picot (Siel)

Sébastien Pollet (Siel) science communication and

outreach

decison support systems

agent

analyst

macrolalgae and marine

Magnoliophyta (transplantation

expert)

benthic ecology (macrobenthos) researcher

macrolalgae and marine

Magnoliophyta

Conservation biologist

(ornithology)

science communication and

outreach

\section{researcher}

researcher

agent

Director

SIEL 
Table S2: Socio-economic categories of the respondents and comparison with the proportion for the whole population of the Montpellier Urban Area (INSEE RGP 2010). Compared to the total population of the Urban Area of Montpellier (censed in 2006), in the survey intermediate professions and workers were underrepresented, while the category comprising unemployed, students and others was overrepresented, and the proportion of the rest of the socio-economic categories were quite comparable to that of the Urban Area of Montpellier population.

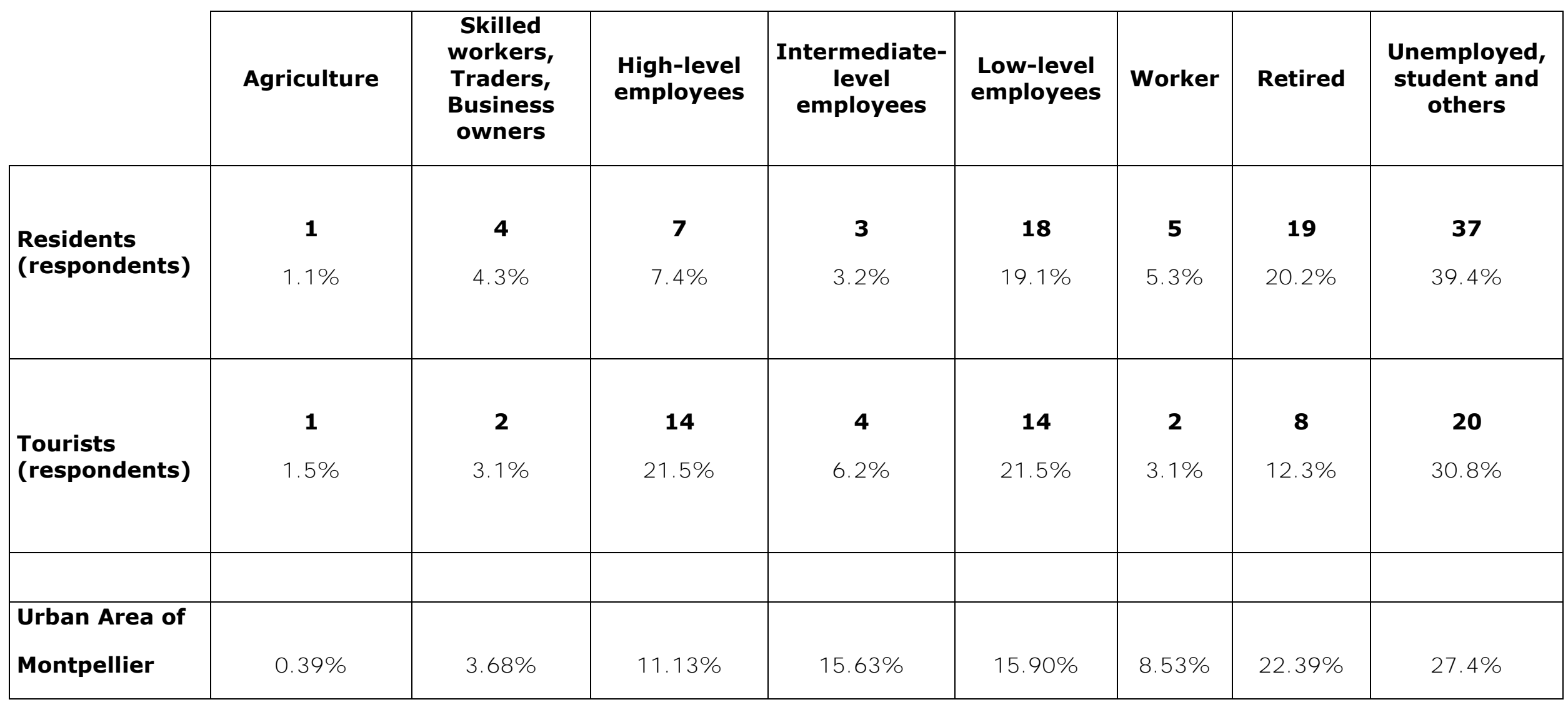


Table S3: Income classes of respondents, declared by the respondents in the Survey. Note that $65 \%$ of the resident respondents informed that they earned less than $2000 €$ per month. The tourist population earned on average more and $45 \%$ of the tourists respondents informed that they earned more than $2000 €$ per month.

\begin{tabular}{|l|c|c|c|c|}
\cline { 2 - 5 } \multicolumn{1}{c|}{} & less than $1000 €$ & $1000-2000 €$ & $\begin{array}{c}\text { more than } \\
2000 €\end{array}$ & do not know \\
\hline Residents & $\mathbf{2 8}$ & $\mathbf{3 3}$ & $\mathbf{3 0}$ & $\mathbf{3}$ \\
& $29.8 \%$ & $35.1 \%$ & $31.9 \%$ & $3.2 \%$ \\
\hline & $\mathbf{1 2}$ & $\mathbf{1 8}$ & $\mathbf{2 9}$ & $\mathbf{6}$ \\
\hline & $18.5 \%$ & $27.7 \%$ & $44.6 \%$ & $9.2 \%$ \\
\hline
\end{tabular}


Table S4: Results of the economometric calculations (statistics) to infer WTP for the biodiversity (Magnoliophyta prairies) and access (footpaths and hides) attributes, respectively.

\section{Residents}

\begin{tabular}{|l|l|l|l|}
\hline Variable & Coefficient & Standard Error & T value \\
\hline Constant & $-4,786$ & 2.206 & .0307 \\
\hline M1 & 11.338 & 2.17 & .0000 \\
\hline M2 & 21.366 & 1.88 & .0000 \\
\hline M3 & 29.450 & 2.17 & .0000 \\
\hline Income & .00072 & .00048 & .1406 \\
\hline Age & .0811 & .0412 & .0497 \\
\hline
\end{tabular}
Adjusted R2 : 0.3858 Log likelihood $=-1410.063$
\begin{tabular}{|l|l|l|l|}
\hline Variable & Coefficient & New R2 & Partial F \\
\hline AM1 additional variables : & .3945 & .0000 \\
\hline AM3 & .0000 & .4072 & 766 \\
\hline & 5.007 & \\
\hline
\end{tabular}

\section{Tourists}

\begin{tabular}{|l|l|l|l|}
\hline Variable & Coefficient & Standard Error & T value \\
\hline Constant & $-2,12$ & 1.449 & .1450 \\
\hline M1 & 3.37 & 1.388 & .0160 \\
\hline M2 & 7.74 & 1.200 & .0000 \\
\hline M3 & 10.02 & 1.368 & .0000 \\
\hline Income & -0.0103 & .0286 & .0002 \\
\hline Age & .10666 & .0004 & .0100 \\
\hline Adjusted R2 : 0.25 Log likelihood $=-735.8$
\end{tabular}

Effect of additional variables :

\begin{tabular}{|l|l|l|l|}
\hline Variable & Coefficient & New R2 & Partial F \\
\hline AM1 & -2.784 & .2726 & .160 \\
\hline AM3 & 2.3864 & .2828 & 3.276 \\
\hline
\end{tabular}




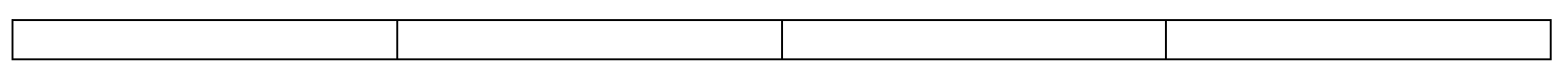

